\title{
Historic variation of trace elements in pinnipeds with spatially segregated trophic habits reveals differences in exposure to pollution
}

\author{
Maite De María ${ }^{\mathrm{a}, *}$, Diana Szteren ${ }^{\mathrm{a}}$, Javier García-Alonso ${ }^{\mathrm{b}}$, Carlos E. de Rezende ${ }^{\mathrm{c}}$, Rodrigo Araújo Gonçalves ${ }^{\mathrm{d}}$, \\ José Marcus Godoy ${ }^{\mathrm{d}}$, Francisco R. Barboza ${ }^{\mathrm{e}}$ \\ a Laboratorio de Zoología de Vertebrados, Departamento de Ecología y Evolución, Facultad de Ciencias, Universidad de la República, Montevideo, Uruguay \\ ${ }^{\mathrm{b}}$ Centro Universitario de la Región Este, Universidad de la República, Uruguay \\ c Laboratory of Environmental Sciences, Universidade Estadual do Norte Fluminense Darcy Ribeiro, Campos dos Goytacazes, Rio de Janeiro, Brazil \\ d Chemistry Department, Pontificia Universidade Católica do Rio de Janeiro, Rio de Janeiro, Brazil \\ e GEOMAR - Helmholtz Centre for Ocean Research Kiel, Kiel, Germany
}

\section{H I G H L I G H T S}

- 70-year analysis of exposure to trace elements in two pinniped species.

- Both species had a higher concentration of Cr during '70-'80s, related to industry development.

- O. byronia with a costal-benthic diet had higher exposure to $\mathrm{Pb}$ and $\mathrm{Cu}$

- A. australis have been more exposed to $\mathrm{Cd}$, associated to their pelagic diet.

- Dentin is a reliable matrix to analyze trace element concentration in pinnipeds.

\section{A R T I C L E I N F O}

\section{Article history:}

Received 17 May 2020

Received in revised form 24 July 2020

Accepted 25 July 2020

Available online 8 August 2020

Editor: Filip M.G. Tack

\section{Keywords:}

Stable isotopes

Marine mammals

ICP-MS

Trophic ecology

Ecotoxicology

\section{G R A P H I C A L A B S T R A C T}

Spatial trophic segregation determines differential exposure to trace elements in two species of pinnipeds. Arctocephalus australis was more exposed to cadmium due to their offshore pelagic diet (based on squid), while Otaria byronia has been more exposed to lead and cooper associated to their coastal and benthic diet during the 20th century. Both species showed an increase of chromium exposure in the '70-'80s that coincides with the development of the tannery industry in the area.

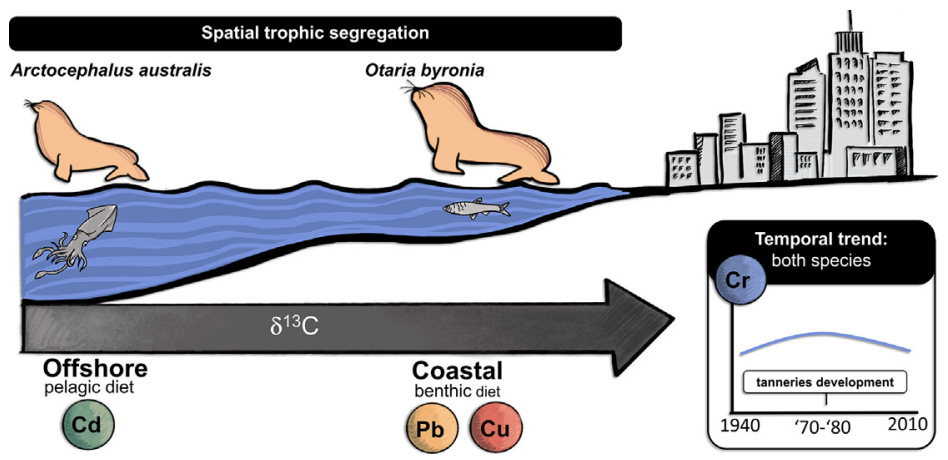

\begin{abstract}
A B S T R A C T
Marine mammals and the ecological functions they provide to coastal and pelagic ecosystems are increasingly threatened by the intensification of anthropogenic impacts. The Uruguayan coastline throughout the 20th century, like other coastal environments worldwide, has been the sink of a variety of trace metals derived from the rapid urbanization and industrialization of related land areas. This coastline is inhabited by two species of pinnipeds trophically and spatially segregated. Otaria byronia feeds in coastal environments while Arctocephalus australis preys mainly offshore. The present study aimed to analyze historic changes in concentrations of trace elements in teeth of both species from 1941 to the present day. We analyzed the dentin of 94 canine teeth using stable isotope analysis $\left(\delta^{13} \mathrm{C}\right)$ and ICP-MS to determine their feeding areas and the concentration of 10 trace elements ( $\mathrm{Al}, \mathrm{As}, \mathrm{Cd}, \mathrm{Cr}, \mathrm{Cu}, \mathrm{Fe}, \mathrm{Mn}, \mathrm{Ni}, \mathrm{Pb}$, and $\mathrm{Zn}$ ) respectively. The concentration of $\mathrm{Cr}$ was significantly higher during '70-'80s, in both species coinciding with tannery industry development. Both species of pinnipeds have been differentially exposed to trace elements depending on their feeding area. A pelagic diet, possibly based on squid, increased the concentration of $\mathrm{Cd}$ in $A$. australis, while $O$. byronia has been more exposed to
\end{abstract}

\footnotetext{
* Corresponding author at: Department of Physiological Sciences, College of Veterinary Medicine, University of Florida, Gainesville, USA.

E-mail addresses: maitedmm@gmail.com (M. De María), diana@fcien.edu.uy (D. Szteren), jgalonso@cure.edu.uy (J. García-Alonso), crezende@uenf.br (C.E. de Rezende), rodrigoag@puc-rio.br (R. Araújo Gonçalves), jmgodoy@puc-rio.br (J.M. Godoy), fbarboza@geomar.de (F.R. Barboza).
} 
anthropogenic $\mathrm{Pb}$ and $\mathrm{Cu}$ associated to a costal and more benthic diet. Our results highlight dentin as a reliable matrix for historic studies on the exposure to trace elements. In light of our results, the O. byronia's declining population could be the result of the synergistic effects of trace elements together with other ecological pressures faced in their environment.

(C) 2020 Elsevier B.V. All rights reserved.

\section{Introduction}

Marine mammals play a key role in the structure and dynamic of the communities because of their large body size and abundance (Bowen, 1997; Gotelli and Ellison, 2006; Weise et al., 2010). Their longevity, late sexual maturity and low reproductive rate make them extremely sensitive to anthropogenic impacts (Fair and Becker, 2000). More than $80 \%$ of humanity lives in coastal environments and our dependence on its services and resources are even larger (Lotze et al., 2006; Worm et al., 2006). Coastal environments are vulnerable to the input of trace elements (Fowler, 1990; Habran et al., 2012) from rivers as dissolved or particulate matter or as the result of burning fossil fuels (Libes, 2009). The major route of trace elements to top predators such as marine mammals is through their diet (Das et al., 2003), which makes them vulnerable to the bioaccumulation of these substances in their tissues if the rate of uptake is greater than the one excretion (Gray, 2002; Reinfelder et al., 1998).

Trace elements are classified depending on their biological functionality in organisms as essential or non-essential (Förstner and Salomons, 1983). Essential elements have a key role in the metabolism but if concentrations are higher than a certain threshold they can become toxic (e.g. cobalt, manganese, selenium, and zinc; Ando et al., 2005). Nonessential elements do not have a biological role and are toxic even at low concentrations (e.g. arsenic, cadmium, lead and mercury). Their presence in the tissues of organisms can indicate an environmental exposure due to natural or anthropic causes (Förstner and Salomons, 1983).

The Uruguayan coastline and the associated Rio de la Plata estuary have been classified as medium-high impacted areas (Halpern et al., 2007) threatened by costal urbanization, intensive agricultural activities, maritime transport and dredging (García-Alonso et al., 2019). Previous research has found high concentrations of trace elements in water and sediments of the region, with historical increases associated with industrialization and urbanization processes of two important capitals, Montevideo (Uruguay) and Buenos Aires (Argentina) (Carsen et al., 2003; García-Rodríguez et al., 2010; Gil et al., 1999; Marcovecchio and Ferrer, 2005; Viana et al., 2005). Even more selective metals are bioaccumulated in polychaetes in urban coastal areas, which can be the entrance of bioavailable metals to coastal trophic networks (Castiglioni et al., 2018).

The coastal area of Uruguay is inhabited by two sympatric pinnipeds species with clear spatial segregation of their trophic habits, Otaria byronia (de Blainville, 1820) (South American sea lion) and Arctocephalus australis (South American fur seal) (Zimmermann, 1783). O. byronia feeds on coastal areas (Franco-Trecu et al., 2014b; Riet Sapriza et al., 2013; Szteren et al., 2018; Vaz-Ferreira and Ponce de León, 1982; Zenteno et al., 2013) while A. australis preys mainly outside the continental shelf, although, it can feed in shallow coastal waters within the Rio de la Plata estuary (Franco-Trecu et al., 2014a; Szteren et al., 2018; Vales et al., 2013). Both species prey mainly on fish, while A. australis also includes pelagic cephalopods as one of the most important dietary items (Franco-Trecu et al., 2012; Naya et al., 2002). Both species have contrasting population trends since 1950, where both species had approximately 30,000 individuals (Vaz-Ferreira, 1976; VazFerreira and Ponce de León, 1982). The population size of 0 . byronia decreased $2 \%$ annually over the last 60 years to $10,000-12,000$ individuals currently (Franco-Trecu et al., 2014b; Páez, 2006), while A. australis official survey estimates the population size to be 300,000 individuals with an annual growth rate of $1 \%$ (Páez, 2006).

The quantification of trace elements in organisms' tissues provides information about their bioavailability, distribution and fate in the marine ecosystem (Kurucz et al., 1998). Bioaccumulation and chronic exposure to trace elements could affect the health and survival of marine mammals (Fair and Becker, 2000) and result in the decline of their populations (Barron et al., 2003; Becker and Krahn, 2000). To understand the fate of contaminants and trace elements in marine ecosystems, it is necessary to analyze them in the context of the trophic network (Van de Vijver et al., 2003). For this purpose, stable isotope analysis has proven to be a useful tool to reconstruct the diet of organisms (Boecklen et al., 2011; Dehn et al., 2006). Particularly, $\delta^{15} \mathrm{~N}$ and $\delta^{13} \mathrm{C}$ provide relevant information on the trophic position and the origin of organic matter in the ecosystem (Fry, 2006; Kelly, 2000; Post, 2002).

Lead, $\mathrm{Hg}, \mathrm{Cd}, \mathrm{Cu}, \mathrm{Zn}$ and $\mathrm{Cr}$ (among others elements) have been quantified in tissues of marine mammal from the Southwest Atlantic Ocean (Kunito et al., 2004; Lemos et al., 2013; Panebianco et al., 2012). Different tissues provide information regarding the diet of the organism and exposure to contaminants across different time scales depending on their turnover rate (Hobson and Sease, 1998; Vander Zanden and W. Fetzer, 2007). The low turnover rate of calcified matrixes, such as teeth and bone, makes them excellent long-term sampling tissues that integrate isotopic relationships and trace element concentrations throughout the life of organisms (Evans et al., 1995; Hirons et al., 2001). In particular, the yearly generation of a new growth layer in teeth allows for reliable reconstructions across the organisms lifetime (Hobson and Sease, 1998; Klevezal, 1996). In this context, bone and teeth have been used to assess the environmental exposure to trace elements in marine mammals (Yamamoto et al., 1987; Outridge and Stewart, 1999). Teeth incorporate trace elements during their formation by three possible mechanisms of deposition (Levine, 2011). The first mechanism is the incorporation of trace elements by isomorphic substitution (Farlay and Boivin, 2012). Divalent ions substitute calcium $\left(\mathrm{Ca}^{2+}\right)$ while trivalent ions can substitute the phosphate group $\left(\mathrm{PO}_{4}^{3-}\right)$ (Wakamura et al., 2000). Secondly, trace elements may co-precipitate with calcium in the formation sites and be incorporated into the hydroxyapatite crystals (Blumenthal, 1990). Lastly, trace elements could be bound to the organic components of the calcified matrixes such as proteins (Triffitt, 1985). For example, $\mathrm{Pb}$ and Cd can be incorporated into the skeleton, because of its similarity to calcium (Bronner and Stein, 1992) and it contains 90\% of the body burden in seals (Kakuschke et al., 2006). Cadmium is also present in calcified matrices as part of the organic portion (osteoblasts and osteoclasts) bound to metallothionines as a detoxification mechanism (Sogawa et al., 2001). Zinc concentration in human teeth has been considered as a possible indicator of environmental exposure to this trace element (Tvinnereim et al., 1999).

The aim of the present study is to analyze historic changes in concentrations of trace elements in teeth of $O$. byronia and A. australis in the Uruguayan coastline from 1941 until 2010. Our working hypothesis is that the concentration of trace elements will increase in the last 7 decades accompanying the urbanization and industrialization of the areas and that the concentration of trace elements will be associated with the feeding area of both species of pinnipeds. We predict higher concentration of non-essential trace elements (such as $\mathrm{Pb}$ and $\mathrm{Cr}$ ) in coastal diets, more common in 0 . byronia than in A. australis. 


\section{Materials and methods}

We sampled canine teeth of $A$. australis and $O$. byronia from to two scientific skull collections: Facultad de Ciencias, Universidad de la República (Montevideo, Uruguay) and the Museo Nacional de Historia Natural (Montevideo, Uruguay). We used teeth because the yearly deposition of dentin growth layers allows for lifetime reconstructions (Hobson and Sease, 1998; Klevezal, 1996). In addition, the dentin, is much less affected by post-mortem decomposition processes driven both by physical-chemical and biological factors due to its hardness, avascular and largely acellular nature (Turner-Walker, 2008). In the particular case of Uruguay, teeth are the only structures with historic records besides skulls for historic reconstructions as the one presented here. We sampled 94 teeth, 33 from 0 . byronia and 61 from A. australis. Teeth belonged to animals stranded along the Uruguayan coastline or collected during controlled harvest at the breeding colonies from 1944 to 2013. Thirty-nine canine teeth were collected in the Department of Rocha, 49 in Maldonado, 3 in Canelones, 1 in Montevideo and 2 in San José (Fig. 1). Sex was determined, whenever it was not present in the collection records, using teeth measurements of crown and root. For this, we used the method suggested by Lowry and Folk (1990) for sea lions and chosen by Molina-Schiller and Pinnedo (2004) as the most accurate for A. australis. To age all individuals, an upper canine tooth was cut longitudinally with a diamond wire-saw (Isomet), from root to crown, then one half was placed in formic acid 10\% for one-two hours, and annual growth layers were counted (Szteren et al., 2018).

\subsection{Stable isotope analysis}

Dentin samples were collected from every growth layer except from the fetal one as described in Szteren et al. (2018). This procedure was performed with a high precision Micro Mill drill (New Wave Research), which extracted a $300 \mu \mathrm{m}$ wide and $500 \mu \mathrm{m}$ deep sample from each growth layer. Afterward, dental collagen was extracted by demineralization with 3 washes of hydrochloric acid (10\%) and a final rinse with distilled water. Then, $1 \mathrm{mg}$ was weighed into tin capsules and kept dry until analysis. Finally, the samples were sent to the University of California Davis for carbon and nitrogen analysis with an isotope ratio mass spectrometer.

Stable isotope abundances were expressed in delta notation as the variation of stable isotope ratios from international standards. This delta notation was expressed in per mil (\%) and calculated as:

$\delta^{15} \mathrm{~N}$ or $\delta^{13} \mathrm{C}=\left(\left(\mathrm{R}_{\text {sample }} / \mathrm{R}_{\text {standard }}\right)-1\right) * 1000 \%$

where $\mathrm{R}_{\text {sample }}$ and $\mathrm{R}_{\text {standard }}$ are the corresponding stable isotope ratio between ${ }^{13} \mathrm{C} /{ }^{12} \mathrm{C}$ or ${ }^{15} \mathrm{~N} /{ }^{14} \mathrm{~N}$. The international standard references were

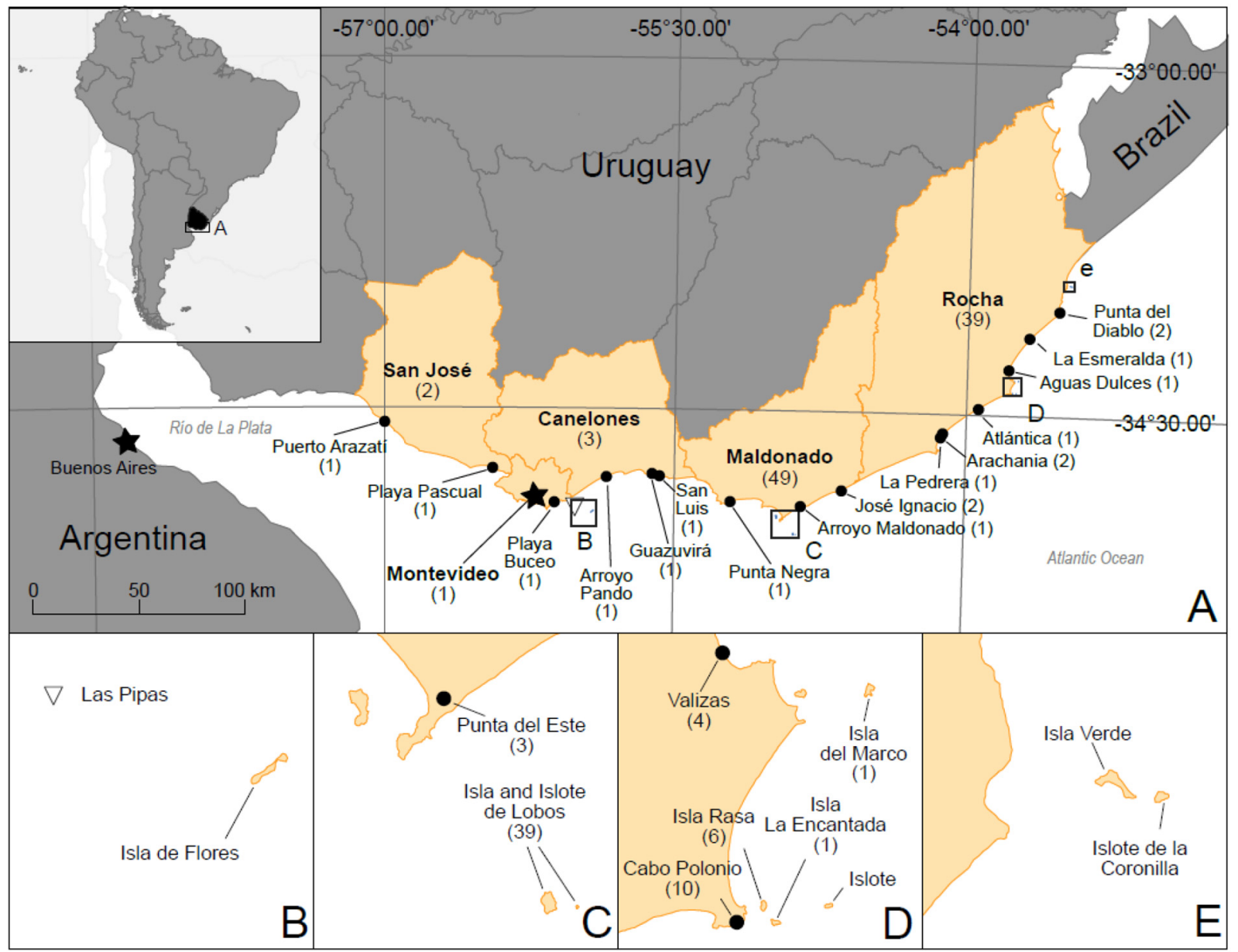

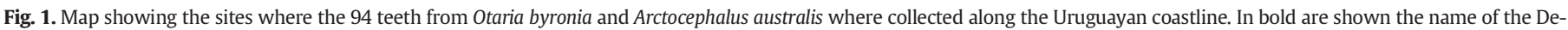

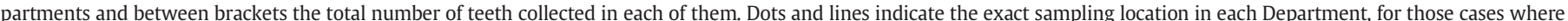

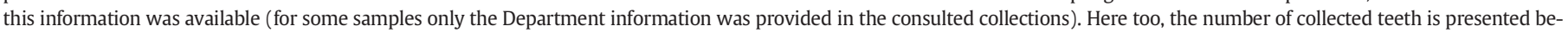

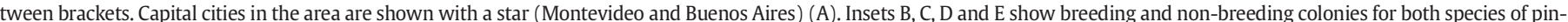

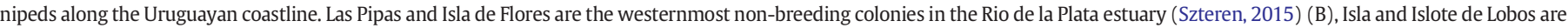

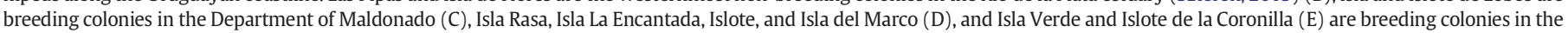
Department of Rocha (Vaz-Ferreira, 1960) (E). 
Pee Dee Belemnite calcium carbonate for $\delta^{13} \mathrm{C}$ and atmospheric Nitrogen (Air, $\mathrm{N}_{2}$ ) for $\delta^{15} \mathrm{~N}$. Based on the difference in $\delta^{13} \mathrm{C}$, it is possible to distinguish between carbon sources from pelagic and oceanic, or benthic and nearshore feeding areas (Hobson et al., 1996). Coastal and nearshore environments are enriched in ${ }^{13} \mathrm{C}$ and, therefore, their signal is higher than in pelagic environments (Burton and Koch, 1999). Stable isotopes are useful tools for the interpretation of trace element accumulation in the context of differences in feeding areas, trophic position and prey (Habran et al., 2012; Jakimska et al., 2011; Marcovecchio et al., 1994).

\subsection{Trace elements analysis}

For trace element analysis, the other half tooth was carefully cleaned up to avoid possible contamination due to storage. A sequential leaching protocol was followed according to Shafer et al. (2008) with hydroxide peroxide (50\%), acetone and lastly with nitric acid ( $0.1 \mathrm{M})$ wash. The first wash was meant to eliminate general contamination, acetone for organic contaminants and nitric acid for inorganic contaminants in general. After every wash, the tooth-half was rinsed with Milli-Q ${ }^{\circledR}$ water. All laboratory materials were acid washed, and the tooth-half was manipulated with Teflon forceps. Each sample was dried at $60{ }^{\circ} \mathrm{C}$ for $1 \mathrm{~h}$ and $200 \mathrm{mg}$ of dentin was sampled with a diamond handpiece on a manual low-speed drill (Saeyang Marathon ${ }^{\circledR}$ ). All growth layers, except the fetal one, where sampled homogeneously. Lastly, samples were digested overnight in $2 \mathrm{~mL}$ of supra pure nitric acid. The concentrations of $\mathrm{As}, \mathrm{Al}, \mathrm{Cd}, \mathrm{Cu}, \mathrm{Cr}, \mathrm{Fe}, \mathrm{Mn}, \mathrm{Ni}, \mathrm{Pb}$, and $\mathrm{Zn}$ were determined considering that these elements are frequently found in urbanized areas (Poleto et al., 2009). Trace element concentrations were determined using a multi-element inductively coupled plasma mass spectrometry (ICPMS, 7500 CX Agilent Technologies Tokyo, Japan) at the Chemistry Department of the Pontifícia Universidade Católica do Rio de Janeiro (Brazil). One of the main advantages of ICP-MS is the high sensitivity compared with other analytical methods, making it an ideal tool for analyzing accumulation in organisms, as previously shown for teeth samples (Webb et al., 2005). Quality assurance was done through analysis of standard reference bone ash (NIST 1400) provided by the National Institute of Standards \& Technology. The ICP-MS operating conditions and measurement parameters are shown in Supplementary Table 1. The recovery was between $94 \%$ and $100 \%$ for all trace elements, except for $\mathrm{Cr}$ and Ni that are not present in the standard reference. Detection limits, in $\mu \mathrm{g} \mathrm{g}^{-1}$ by dry weight, were: As 0.002 , Al 0.095 , Cd $0.0005, \mathrm{Cr} 0.005$, Cu 0.055, Fe 38.4, Mn 0.005, Ni 0.020, Pb 0.001, and Zn 0.008. Concentrations were calculated using blank subtraction and linear fit standardization of Rhodium $\left({ }^{103} \mathrm{Rh}\right)$. To determine the concentration of Fe, each sample needed to be diluted $(1: 101)$. To perform the statistical analysis in case samples exhibited concentrations below the detection limit, half of this value was considered. A maximum of 2 observations under the detection limit was registered for each element, except for As where 60 out of 94 samples were below the detection limit.

\subsection{Statistical analysis}

Each individual sample was assigned to a particular year of the considered time frame (1941-2010) which corresponded with half of their lifespan. This year was calculated based on the year of death and age of individuals as: yearofdeath $-\frac{a g e}{2}$. In case the individual had lived an odd number of years, the year was determined by rounding the obtained result to the nearest unit. Therefore, samples were collected from 1944 to 2013 but our individuals were assigned to the time frame 1941-2010. For each animal, stable isotope values were calculated as the average of all growth layers $\left(\delta^{13} \mathrm{C}\right.$ and $\left.\delta^{15} \mathrm{~N}\right)$. The carbon values were corrected considering the Suess effect using the same methodology as in Szteren et al. (2018). This effect is an environmental change in the proportion of ${ }^{13} \mathrm{C}$ and ${ }^{12} \mathrm{C}$ due to the release of $\mathrm{CO}_{2}$ from fossil fuel burning, which produces a systematic and constant decrease of $\delta^{13} \mathrm{C}$ (Cullen et al., 2001; Francey et al., 2002; Hanson et al., 2009). This is why, to compare trace element concentrations considering $\delta^{13} \mathrm{C}$ from animals that have lived in different periods during the last 70 years, carbon values were corrected as follows:

for animals that lived before 1960 ,

$\delta^{13} C_{\text {corrected }}=\delta^{13} \mathrm{C}-0.005 \mathrm{x}$ (Numbers of years to 1960$)-0.022 \times(53)$

for animals that lived after 1960 ,

$\delta^{13} C_{\text {corrected }}=\delta^{13} \mathrm{C}-0.022 \mathrm{x}$ (Numbers of years to 2013 )

Trace element concentrations were analyzed with generalized linear models (GLM), adjusted using the function $\mathrm{glm}$ from the R package stats (R Core Team, 2019). Age, $\delta^{13} \mathrm{C}$, sex and year were considered explanatory variables. Given the normal or log-normal distributions that characterize element concentrations, the Gaussian distribution and identity link function were used for fitting GLM, applying a logarithmic transformation when required. The identity link function was used in all fitted models. Models derived from all possible combinations of candidate explanatory variables were automatically generated and ranked based on the Akaike's Information Criterion (AIC) using the function dredge from the package MuMIn (Barton, 2019) (Supplementary Table 2). Models with the lowest AIC values were retained as the best ones.

The identity of species was not considered as an explanatory variable in the GLM because A. australis and 0 . byronia exhibit spatial trophic segregation and this was already represented in the models by $\delta^{13} \mathrm{C}$. Trophic segregation has been determined through different methods, including stable isotope analysis (see further evidence in Drago et al., 2015; Franco-Trecu et al., 2014a, Franco-Trecu et al., 2012; Szteren et al., 2018). The carbon and nitrogen isotope values of both species of pinniped showed a high and significant correlation over the 70 years considered in the study (Pearson's correlation, $R=0.58, p<0.001$ ) (Supplementary Fig. 1). This association is due to the fact that coastal prey not only have higher values of $\delta^{13} \mathrm{C}$ but also higher $\delta^{15} \mathrm{~N}$ that is reflected in their predators (Franco-Trecu et al., 2012). Therefore, to avoid collinearity only one variable could be included in the models and we chose $\delta^{13} \mathrm{C}$ for three reasons. 1) Both species of pinnipeds showed a stronger segregation in relation to $\delta^{13} \mathrm{C}$ than $\delta^{15} \mathrm{~N}$ (Drago et al., 2017; Szteren et al., 2018), and the difference in $\delta^{15} \mathrm{~N}$ was less than $3-5 \%$, values used to determine if species belong or not to different trophic levels (Deniro and Epstein, 1981; Michner and Kaufman, 2007). 2) None of the analyzed trace elements bioaccumulate with the increase in trophic position (Won et al., 2018).3). We analyzed the concentration of trace elements associated to anthropogenic activities (Poleto et al., 2009) which are mainly transported from the land, particularly from cities and industries, by rivers and atmospheric fluxes into the estuaries and, then, into the oceans (Libes, 2009). In this context, the spatial information provided by $\delta^{13} \mathrm{C}$ on the origin of organic matter results particularly explanatory.

The adequacy of fitted models was evaluated through a detailed visual inspection of residual plots. In case the explanatory variables, $\delta^{15} \mathrm{~N}$, Sex, age and year were not retained as relevant explanatory variables in the modeling process, the residuals of the selected model were analyzed against these variables to evaluate potential trends not detected (Supplementary Figs. 2, 3, 4 and 5).

\section{Results}

3.1. Profile of trace elements in the dentin of Otaria byronia and Arctocephalus australis

Both species had very similar trace element relative concentrations, with Fe as the element with the greatest concentration, followed by $\mathrm{Zn}$, 
$\mathrm{Al}$ and $\mathrm{Ni}$ (Table 1). In decreasing order, A. australis had $\mathrm{Fe}>>\mathrm{Zn}>\mathrm{Al}>$ $\mathrm{Ni}>\mathrm{Mn}>\mathrm{Cu}>\mathrm{Cr}>\mathrm{Pb}>\mathrm{Cd}$, while in 0 . byronia $\mathrm{Cu}$ and $\mathrm{Mn}$ had similar concentrations and $\mathrm{Pb}$ values were higher than those for $\mathrm{Cr}$ (Table 2). Arsenic was detected only in 34 samples. When it was detected, the mean concentration was $0.01 \pm 0.03$ (standard deviation) $\mu \mathrm{g} \mathrm{g}{ }^{-1}$ dry weight for A. australis and for 0 . byronia was $0.009 \pm 0.02 \mu \mathrm{g} \mathrm{g}{ }^{-1}$ dry weight.

\subsection{Concentration of trace elements according to year, $\delta^{13} C$, sex and age}

None of the included explanatory variables statistically contributed to explaining $\mathrm{Fe}, \mathrm{Ni}, \mathrm{Mn}, \mathrm{Zn}$ and $\mathrm{Al}$ concentrations. The concentration of these elements in the dentin of $A$. australis and $O$. byronia has remained almost the same for 70 years considered in the study, despite $\delta^{13} \mathrm{C}$, age and sex.

Chromium concentrations changed from 1941 to 2010 following a second-order polynomial function for both species with a maximum concentration during 1970-1980, being significantly higher in males than females during the entire study period (Table 2, Fig. 2). The explained deviance of the model was $16 \%$ (Supplementary Table 2). In the case of $\mathrm{Cd}, \mathrm{Cu}$ and $\mathrm{Pb}$, the concentration varied significantly with $\delta^{13} \mathrm{C}$ for both species of pinnipeds, not showing temporal trends (Table 2, Fig. 3). Cadmium concentration decreased linearly with $\delta^{13} \mathrm{C}$, and males had significantly higher concentration than females (Fig. 3A, Table 2), explaining $33.1 \%$ of the deviance (Supplementary Table 2). Higher concentrations of $\mathrm{Cd}$ were found in individuals with lower $\delta^{13} \mathrm{C}$, i.e., those particularly observed in A. australis. In the case of $\mathrm{Cu}$, concentrations increased linearly with $\delta^{13} \mathrm{C}$, but no significant differences were observed between sexes (Fig. 3B, Table 2). The model for $\mathrm{Cu}$ explained $11 \%$ of the deviance (Supplementary Table 2). Lead concentrations increased linearly with $\delta^{13} \mathrm{C}$ and males had higher concentrations than females for the 70 years of analysis (Fig. 3C, Table 2). For $\mathrm{Pb}$, the model explained $20 \%$ of the deviance (Supplementary Table 2 ). The concentration of $\mathrm{Cu}$ and $\mathrm{Pb}$ increased towards higher values of $\delta^{13} \mathrm{C}$, i.e., those particularly observed in $\mathrm{O}$. byronia.

\section{Discussion}

The dentin of both species of pinnipeds showed quantifiable concentrations of trace elements. Concentrations of $\mathrm{Fe}, \mathrm{Al}, \mathrm{Mn}, \mathrm{Ni}$, and $\mathrm{Zn}$ did not show significant changes over the last 70 years, regardless of the age of individuals and the differences in feeding areas between species of pinnipeds. Therefore, the concentrations of these elements could be used as a reference for analyses of dentin trace element composition in $A$. australis and 0 . byronia in the study area. Iron was the most abundant trace element in both species, coinciding with previous analysis of calcified matrixes in marine mammals (Ando et al., 2005; Edmonds et al., 1997; Fujise et al., 1988; Honda et al., 1986; Yamamoto et al., 1987). However, the concentration of Fe did vary between species (Table 1). The presence of Fe in the dentin may be associated with physiological processes in the odontoblastic cells in charge of the synthesis and maturation of the matrix (Piesco, 1994; Tjäderhane et al., 2012) more than an environmental exposure. In comparison with other species, $A$. australis and $O$. byronia showed high Fe concentrations than, e.g., Leptonychotes weddellii in the Antarctic (Table 1, Yamamoto et al., 1987). This could be related to the high bioavailability of this element in the Uruguayan coastline where it can present concentrations between 2 and $12 \mathrm{mg} \mathrm{g}^{-1}$ dry weight (García-Alonso et al., 2017).

Zinc was the second most abundant element present in the dentin of both species of pinnipeds and the concentrations found were very similar to those observed in $L$. weddellii (Table 1, Yamamoto et al., 1987). In human bone, the concentration of $\mathrm{Zn}$ varied from 60 to $310 \mu \mathrm{g} \mathrm{g}^{-1}$ dry weight between and is considered to have a strong physiological regulation (Shafer et al., 2008). Thus, the concentration range found in our study could be considered normal in the dentin of pinnipeds despite the presence of $\mathrm{Zn}$ enrichment in Montevideo sediments, where this element can reach concentrations 8 times higher than the earth's crust average (García-Alonso et al., 2017). Aluminum is the third most abundant element in the Earth's crust (Martin, 2006) and the main form of uptake by mammals is through the diet. Previous studies have reported the Al concentrations in total and the reactive fractions of sediments as well as in organisms of the Uruguayan coastline (García-Alonso et al., 2017) and, therefore, are likely to be incorporated into the bone (Priest, 1993) and dentin of pinnipeds. The range of Mn concentrations in both species of pinnipeds was similar to that found in other calcified matrixes of marine mammals (Table 1) (Agusa et al., 2011; Honda et al., 1986; Yamamoto et al., 1987). The presence of Mn in dentin could be a common metabolic requirement as suggested by previous studies (Arora et al., 2012).

Non-essential trace elements in A. australis and 0 . byronia, such as $\mathrm{Cd}, \mathrm{Cr}$ and $\mathrm{Pb}$; and $\mathrm{Cu}$, showed either temporal or spatial trends in the last 70 years.

\subsection{Temporal trend}

Chromium was the only trace element that significantly changed over the last 70 years in pinnipeds dentin. Recent evidence shows that $\mathrm{Cr}$ cannot be considered an essential trace element because there is no data, up to our knowledge, on the biological effects of its deficiency or that its supplementation relieves symptoms (Vincent, 2013). Trivalent $\mathrm{Cr}$ is associated with glucose metabolism and rarely produces toxicity, while hexavalent $\mathrm{Cr}$ is toxic, and its compounds are irritant and corrosive. Unfortunately, the valence of $\mathrm{Cr}$ measured in the present and previous studies cannot be identified. Chromium is used as a dye for textiles, particularly for tanning leather (Covington et al., 2001). Because of its capacity to bind collagen, $\mathrm{Cr}$ can be easily analyzed in the dentin as shown in our research, in which collagen is the main protein (Butler, 1995; Silvestre et al., 1994). Argentina and Brazil are among the largest producers of leather in the world (FAO, 2013). Marine mammals rarely have $\mathrm{Cr}$ exposure, even when analyzing liver concentrations (Stockin et al., 2007; Szefer et al., 1994; Zhou et al., 2001), however, it has been detected in all dolphin samples from the South of Brazil, and Argentina (Kunito et al., 2004; Panebianco et al., 2012). Leather industries have pushed Uruguay's economy during the studied period (Instituto Cuesta Duarte, 2005). Chromium is the main effluent of tanneries located very close to the Pantanoso river that flows to Montevideo Bay in the Rio de la Plata estuary (Feola et al., 2013; Muniz et al., 2004a). Leather manufacturing in Uruguay increased during the 20th century, in the '70-'80s reached its maximum production, followed by a reduction during the '90s (Instituto Cuesta Duarte, 2005). The increase in $\mathrm{Cr}$ concentrations in dentin from 1941 until 1980 correlates with the increase of this element concentration in Montevideo Bay sediments for the same period (Burone et al., 2013; García-Rodríguez et al., 2010). Since 1993, the Cr effluent from tanneries has decreased to only $2 \%$ of the historic loads in rivers (Feola et al., 2013; Rafaelle, 2012) after wastewater treatment systems were installed (Lacerda et al., 1998). The concentration found in dentin of pinnipeds is below what is considered the average for environmentally exposed humans $\left(50 \pm 22 \mu \mathrm{g} \mathrm{g}^{-1}\right.$ ) (Nowak and Chmielnicka, 2000), despite the fact that the enrichment factor for Uruguayan coastline sediments could reach values up to 4.6 times when compared to the average concentration in the Earth's crust (García-Alonso et al., 2017).

\subsection{Spatial segregation of trophic habits and differential exposure}

In the last 70 years, the concentration of $\mathrm{Cd}, \mathrm{Cu}$ and $\mathrm{Pb}$ in the dentin of both species of pinnipeds significantly changed depending on their feeding areas. The concentration of $\mathrm{Cd}$ in both species of pinnipeds decreases towards higher values of $\delta^{13} \mathrm{C}$, i.e., coastal feeding areas and/or benthic prey. More negative values of $\delta^{13} \mathrm{C}$, corresponding to a more pelagic diet, and higher $\mathrm{Cd}$ concentration were more common in $\mathrm{A}$. australis than $O$. byronia (although some individuals of $O$. byronia 
Table 1

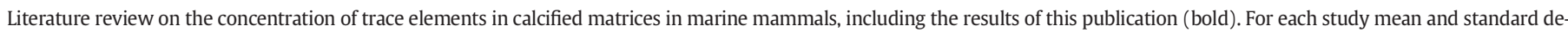
viation (SD) are shown $\left(\mu \mathrm{g} \mathrm{g}^{-1}\right)$. * indicates wet weight.

\begin{tabular}{|c|c|c|c|c|c|}
\hline Trace element & Species & Matrix & Mean & SD & Reference \\
\hline \multirow[t]{7}{*}{$\mathrm{Fe}$} & Atrocephalus australis & Teeth & $4.85\left(\mathrm{mg} \mathrm{g}^{-1}\right)$ & 1.81 & This study \\
\hline & Otaria byronia & Teeth & $4.88\left(\mathrm{mg} \mathrm{g}^{-1}\right)$ & 1.80 & This study \\
\hline & Dugong dugon & Teeth & $6.4\left(\mathrm{mg} \mathrm{g}^{-1}\right)$ & 3.2 & (Edmonds et al., 1997) \\
\hline & Leptonychotes weddellii & Teeth & $17.9^{*}$ & - & (Yamamoto et al., 1987) \\
\hline & Phocoenoides dalli & Bone & 281 & - & (Fujise et al., 1988) \\
\hline & Stenella coeruleoalba & Bone & $101^{*}$ & 12.9 & (Honda et al., 1986) \\
\hline & Zalophus californianus & Bone & 58.81 & - & (Szteren and Aurioles-Gamboa, 2013) \\
\hline \multirow[t]{8}{*}{$\mathrm{Zn}$} & Arctocephalus australis & Teeth & 105.4 & 46.0 & This study \\
\hline & Otaria byronia & Teeth & 81.8 & 24.8 & This study \\
\hline & Leptonychotes weddellii & Teeth & $101^{*}$ & - & (Yamamoto et al., 1987) \\
\hline & & Bone & 87.8 & - & (Yamamoto et al., 1987) \\
\hline & Stenella coeruleoalba & Bone & $409^{*}$ & 39 & (Honda et al., 1986) \\
\hline & Phoca vitulina & Bone & 98.0 & - & (Agusa et al., 2011) \\
\hline & Phocoenoides dalli & Bone & $296^{*}$ & - & (Fujise et al., 1988) \\
\hline & Zalophus californianus & Bone & $60.78^{*}$ & - & (Szteren and Aurioles-Gamboa, 2013) \\
\hline \multirow[t]{3}{*}{$\mathrm{Al}$} & Arctocephalus australis & Teeth & 29.6 & 42.6 & This study \\
\hline & Otaria byronia & Teeth & 18.6 & 24.8 & This study \\
\hline & Zalophus californianus & Bone & 73.70 & - & (Szteren and Aurioles-Gamboa, 2013) \\
\hline \multirow[t]{4}{*}{$\mathrm{Ni}$} & Arctocephalus australis & Teeth & 4.06 & 1.87 & This study \\
\hline & Otaria byronia & Teeth & 3.67 & 1.36 & This study \\
\hline & Stenella coeruleoalba & Bone & $0.08^{*}$ & 0.05 & (Honda et al., 1986) \\
\hline & Phocoenoides dalli & Bone & 0.22 & - & (Fujise et al., 1988) \\
\hline \multirow[t]{7}{*}{ Mn } & Arctocephalus australis & Teeth & 1.07 & 0.39 & This study \\
\hline & Otaria byronia & Teeth & 0.96 & 0.26 & This study \\
\hline & Stenella coeruleoalba & Bone & $0.82^{*}$ & 0.22 & (Honda et al., 1986) \\
\hline & Leptonychotes weddellii & Teeth & $1.35^{*}$ & - & (Yamamoto et al., 1987) \\
\hline & Phoca vitulina & Bone & 0.67 & - & (Agusa et al., 2011) \\
\hline & Phocoenoides dalli & Bone & 0.55 & - & (Fujise et al., 1988) \\
\hline & Obdobenus rosmarus rosmarus & Teeth & - & $0.17(\min )-1.24(\max )$ & (Outridge and Stewart, 1999) \\
\hline \multirow[t]{7}{*}{$\mathrm{Cu}$} & Arctocephalus australis & Teeth & 0.83 & 0.85 & This study \\
\hline & Otaria byronia & Teeth & 1.39 & 1.10 & This study \\
\hline & Delphinapterus leucas & Teeth & $0.17^{*}$ & - & (Outridge et al., 1997) \\
\hline & Leptonychotes weddellii & Teeth & $0.42^{*}$ & - & (Yamamoto et al., 1987) \\
\hline & & Bone & $0.77^{*}$ & - & (Yamamoto et al., 1987) \\
\hline & Odobenus rosrnams & Teeth & $0.44^{*}$ & - & (Outridge et al., 1997) \\
\hline & Stenella coeruleoalba & Bone & $0.48^{*}$ & 0.01 & (Honda et al., 1986) \\
\hline \multirow[t]{3}{*}{$\mathrm{Cr}$} & Arctocephalus australis & Teeth & 0.17 & 0.17 & This study \\
\hline & Otaria byronia & Teeth & 0.14 & 0.09 & This study \\
\hline & Phoca vitulina & Bone & 0.093 & - & (Agusa et al., 2011) \\
\hline \multirow[t]{15}{*}{$\mathrm{Pb}$} & Arctocephalus australis & Teeth & 0.17 & 0.12 & This study \\
\hline & Otaria byronia & Teeth & 0.42 & 0.41 & This study \\
\hline & & Bone & $1.6^{*}$ & 0.2 & (Peña et al., 1988) \\
\hline & Delphinus leucas & Teeth & 0.16 & 0.04 & (Kinghorn et al., 2008) \\
\hline & Delphinapterus leucas & Teeth & $0.2^{*}$ & - & (Outridge et al., 1997) \\
\hline & Eumetopias jubatus & Teeth & 10.04 & 11.6 & (Ando et al., 2005) \\
\hline & Leptonychotes weddellii & Bone & $0.48^{*}$ & - & (Yamamoto et al., 1987) \\
\hline & & Teeth & $0.48^{*}$ & - & (Yamamoto et al., 1987) \\
\hline & Stenella coeruleoalba & Bone & 0.39 & 0.08 & (Honda et al., 1986) \\
\hline & Odobenus rosrnams & Teeth & $2.0^{*}$ & - & (Outridge et al., 1997) \\
\hline & Phoca vitulina & Bone & 0.11 & - & (Agusa et al., 2011) \\
\hline & Phocoenoides dalli & Bone & $0.15^{*}$ & - & (Fujise et al., 1988) \\
\hline & Trusiops aduncus & Bone & $2.78^{*}$ & 3.07 & (Lavery et al., 2008) \\
\hline & Tursiops truncatus & Bone & $0.85^{*}$ & 0.19 & (Lavery et al., 2008) \\
\hline & Delphinus delphis & Bone & $1.03^{*}$ & 0.55 & (Lavery et al., 2008) \\
\hline \multirow[t]{13}{*}{$\mathrm{Cd}$} & Arctocephalus australis & Teeth & 0.08 & 0.07 & This study \\
\hline & Otaria byronia & Teeth & 0.01 & 0.01 & This study \\
\hline & Delphinapterus leucas & Teeth & 0.029 & - & (Outridge et al., 1997) \\
\hline & Leptonychotes weddellii & Bone & $0.02^{*}$ & - & (Yamamoto et al., 1987) \\
\hline & & Teeth & $0.02^{*}$ & - & (Yamamoto et al., 1987) \\
\hline & Odobenus rosrnams & Teeth & $0.05^{*}$ & - & (Outridge et al., 1997) \\
\hline & Stenella coeruleoalba & Bone & $0.18^{*}$ & 0.05 & (Honda et al., 1986) \\
\hline & Phoca vitulina & Bone & 0.003 & - & (Agusa et al., 2011) \\
\hline & Phocoenoides dalli & Bone & $0.23^{*}$ & - & (Fujise et al., 1988) \\
\hline & Trusiops aduncus & Bone & $0.047^{*}$ & 0.81 & (Lavery et al., 2008) \\
\hline & Tursiops truncatus & Bone & - & - & (Lavery et al., 2008) \\
\hline & Delphinus delphis & Bone & - & - & (Lavery et al., 2008) \\
\hline & Zalophus californianus & Bone & $2.99^{*}$ & - & (Szteren and Aurioles-Gamboa, 2013) \\
\hline
\end{tabular}

showed low values of $\delta^{13} \mathrm{C}$ and matching high Cd concentration). These pinniped species are trophically segregated since the last century (Drago et al., 2017; Szteren et al., 2018). A. australis feeds more on pelagic preys, particularly on squid which make up $40 \%$ of their diet along with anchovies (Engraulis anchoita) (Franco-Trecu et al.,
2013, 2014a; Szteren et al., 2004). Squid accumulate Cd bound to cytosolic proteins in their digestive gland, favoring its transference through the trophic web (Bustamante and Bertrand, 2006). The Argentine shortfin squid (Illex argentines) in the Southwest Atlantic can accumulate up to $485 \mu \mathrm{g} \mathrm{g}^{-1}$ (wet weight) of Cd (Gerpe et al., 2000). E. anchoita 
Table 2

Significant estimates for the corresponding models for trace element concentration. Model coefficients are expressed in R syntax. ${ }^{*} p$-value $<0.05,{ }^{* *}$ p-value $<0.01$ and ${ }^{* * *}$ p-value $<0.001$

\begin{tabular}{llcc}
\hline Model & Coefficient & Estimate & p-value \\
\hline Ln (Cadmium) & Intercept & -9.95 & $<0.001^{* * *}$ \\
& Sex-Male & 1.52 & $<0.001^{* * *}$ \\
& $\delta^{13} \mathrm{C}$ & -0.39 & $0.012^{* *}$ \\
Ln (Chromium) & Intercept & -2.43 & $<0.001^{* * *}$ \\
& Poly(Year,2) 1 & -0.98 & 0.24 \\
& Poly(Year,2) & -2.26 & $0.0078^{* *}$ \\
Ln (Copper) & Sex-Male & 0.41 & $0.029^{*}$ \\
& Intercept & 3.30 & $0.0054^{* *}$ \\
Ln (Lead) & $\delta^{13} C$ & 0.27 & $0.0017^{* *}$ \\
& Estimate & 2.00 & $0.039^{*}$ \\
& Sex-Male & 0.38 & $0.031^{*}$ \\
& $\delta^{13} \mathrm{C}$ & 0.30 & $<0.001^{* * *}$ \\
\hline
\end{tabular}

could also transfer $\mathrm{Cd}$ to both species of pinnipeds, particularly to $A$. australis. The concentration of $\mathrm{Cd}$ in visceral tissue of anchovies can be as high as $3.32 \mu \mathrm{g} \mathrm{g}^{-1}$ (Polizzi et al., 2017). Therefore, our results support previous findings in which A. australis had a higher concentration of Cd than 0 . byronia, in other tissues such as in kidney and liver (Marcovecchio et al., 1994; Tagliamonte, 2009).

Our results show an increase in the concentration of $\mathrm{Cu}$ towards higher $\delta^{13} \mathrm{C}$ values, corresponding to a more coastal and/or benthic diet for both species of pinnipeds, being more common in 0 . byronia. A higher concentration of $\mathrm{Cu}$ can be found in lakes, rivers and estuaries than in the ocean (Georgopoulos et al., 2001). Sediments with up to 135 $\mu \mathrm{g} \mathrm{g}{ }^{-1}$ dry weight concentrations of $\mathrm{Cu}$ in Montevideo Bay are considered to be highly polluted (Muniz et al., 2004a), and Cu was also found in the intertidal sediments (Castiglioni et al., 2018; GarcíaAlonso et al., 2017). The external area of Rio de la Plata estuary also has levels of $\mathrm{Cu}$ that could toxic for the resident biota (Carsen et al., 2003). O. byronia uses more coastal and benthic areas than A. australis and, therefore, has a higher concentration of $\mathrm{Cu}$. These trends have reminded similar for the last 70 years, despite that Montevideo Bay sediments showed a sharp increase in concentrations of Cu before 1940 and another one during the '90s (García-Rodríguez et al., 2010).

The concentration of $\mathrm{Cu}$ in both species of pinnipeds prey has not been studied in detail. Mullet (Mugil platanus) is the most abundant coastal fish species in Uruguay with a high concentration of $\mathrm{Cu}$ (up to

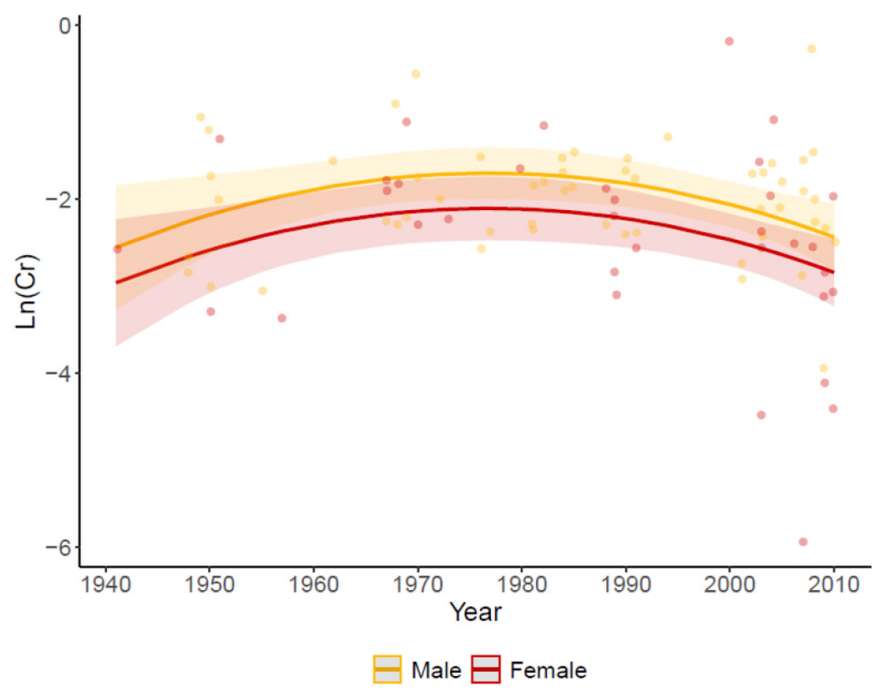

Fig. 2. Temporal trends in the concentration of Chromium ( $\mu \mathrm{g} \mathrm{g} \mathrm{g}^{-1}$ dry weight) for males (red) and females (yellow) of Arctocephalus australis and Otaria byronia during the last 70 years. Solid lines represent mean trends and shaded areas $95 \%$ confidence intervals.
$493 \mu \mathrm{g} \mathrm{g}^{-1}$ dry weight in liver) (Viana et al., 2005). It has not been reported as a common species in the scats of 0 . byronia, but this species of pinniped has been seen eating mullet during the interaction with coastal fisheries (observed by the authors), making it a possible source of $\mathrm{Cu}$ (De María et al., 2014a, 2014b). The Whitemouth croaker (Micropogonias furnieri), Stripped weakfish (Cynoscion guatucupa) and Brazilian codling (Urophyscis brasiliensis) are better represented in 0 . byronia's diet (Franco-Trecu et al., 2013) and have approximately 50 $\mu \mathrm{g} \mathrm{g}^{-1}$ dry weight of $\mathrm{Cu}$ in their livers (Viana et al., 2005). Future research should quantify the concentration of these metals in pelagic fish such as E. anchoita and cephalopods to confirm the possible differential trophic transfer of $\mathrm{Cu}$ from benthic and pelagic preys found in this study. The concentrations of $\mathrm{Cu}$ in $O$. byronia and $A$. australis individuals that prey in coastal environments are above those found in calcified matrixes of other marine mammals from around the world (Table 1). Future studies should address the association between the concentration of $\mathrm{Cu}$ in teeth and other tissues to completely understand its physiological consequences.

The concentrations of $\mathrm{Pb}$ were higher in individuals preying in benthic and coastal environments (i.e. particularly in 0 . byronia) than those feeding in pelagic areas. Higher concentrations of $\mathrm{Pb}$ occur in coastal environments because of the anthropic input associated with cities and burn of fossil fuels (Libes, 2009) as well as several studies indicate that about 82 to $90 \%$ of the organic and inorganic suspended particulate material is retained in the continental shelf and deltas region (Hedges, 1992; Hedges and Keil, 1995). Until 2000, Pb was used as a gasoline additive in Uruguay and Argentina (ANCAP, 2020; MECON, 1998) and it still used in car batteries, paint pigments and ammunition (International Lead and Zinc Study Group, 2020). In Uruguay, there is still recycling and smelting of batteries that are responsible for human exposure to $\mathrm{Pb}$ (Burger and Pose Roman, 2010). Lead has toxic effects in humans, causing central nervous system problems, hypertension and kidney failure (Fowler et al., 2015). The concentration of $\mathrm{Pb}$ in Montevideo Bay sediments is higher than in the adjacent Southwest Atlantic (Muniz et al., 2004b). Moreover, rivers that flow to the Rio de la Plata in Uruguay and Argentina have sediment concentrations that could be toxic for biological communities (Carsen et al., 2003; Feola et al., 2013). Teeth are a trustworthy source of environmental exposure to $\mathrm{Pb}$ in humans (Karahalil et al., 2007) and concentrations over $4 \mu \mathrm{g} \mathrm{g}^{-1}$ dry weight suggests lead intoxication (Al-Mahroos and Al-Saleh, 1997). The concentration of $\mathrm{Pb}$ in both species of pinnipeds did not reach this threshold and, therefore, seem not to be intoxicated with $\mathrm{Pb}$. Based on this threshold for humans, observed concentrations of $\mathrm{Pb}$ in both species of pinnipeds seem not to reach toxic levels. However, studies on the specific-sensitivity of pinnipeds to $\mathrm{Pb}$ are still missing and the definition of critical levels should be addressed in future studies. The concentration of $\mathrm{Pb}$ in Eumetopias jubatus in Asia was higher than in $O$. byronia and A. australis (Table 1, Ando et al., 2005). This could be due to the large differences in $\mathrm{Pb}$ contamination between regions, being much higher in Asia than in South America (Shahidul Islam and Tanaka, 2004). However, the concentration of $\mathrm{Pb}$ found in other marine mammal species in calcified matrixes in the Antarctic and Arctic are similar to the ones found in the present study (less than $2.0 \mu \mathrm{g} \mathrm{g}^{-1}$; Outridge et al., 1997; Outridge and Stewart, 1999; Yamamoto et al., 1987) (Table 1).

Cadmium, $\mathrm{Cr}$ and $\mathrm{Pb}$ showed differences between sexes in both species of pinnipeds, being higher in males than in females. It is possible that larger organisms like males of both species, require a larger energy input (Segura et al., 2015) and this could increase the intake of trace elements. It is also probable that females could deposit less (or even remove) $\mathrm{Cd}$ and $\mathrm{Cr}$ in ossified matrixes during gestation and lactation as it occurs with $\mathrm{Pb}$ (Levine, 2011). Higher concentrations of $\mathrm{Pb}$ found in males than in females could be due to the maternal transference during pregnancy and lactation, as part of the $\mathrm{Ca}$ and $\mathrm{Pb}$ kinetics in the skeleton (Bronner, 2008; Ong et al., 1993; Téllez-Rojo et al., 2002). Particularly, in human studies, the concentration of $\mathrm{Pb}$ is higher in men than in women 


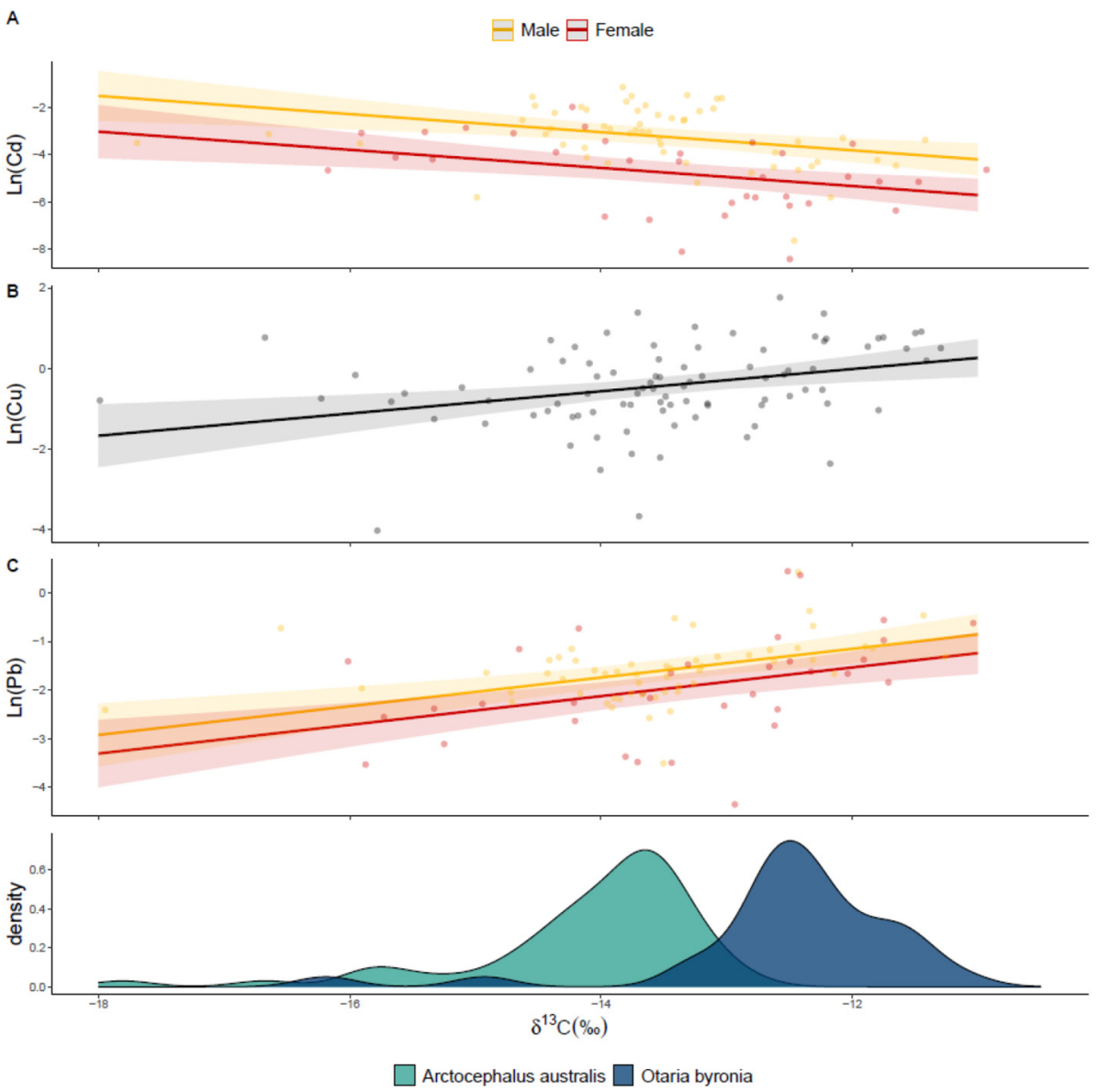

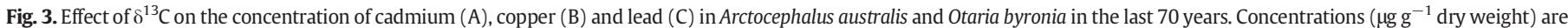

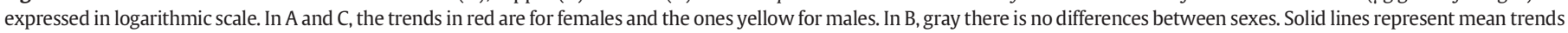
and shaded areas 95\% confidence intervals. Density plots represent the frequency of $\delta^{13} \mathrm{C}$ values for A. australis (green) and 0 . byronia (blue).

(Alomary et al., 2006; Baranowska et al., 2004) and this mechanism of transference has been reported for pinnipeds, e.g. in Halichoerus grypus (Habran et al., 2012). In addition, A. australis females could receive less $\mathrm{Pb}$ through their diet because they consume more pelagic prey than males (Franco-Trecu et al., 2014a). In both species, females are smaller and feed from a lower trophic position than males (Arim et al., 2007; Segura et al., 2015; Szteren et al., 2018), likely reducing the transference of $\mathrm{Pb}$. However, this relationship between trophic level and $\mathrm{Pb}$ has been inconclusive and previous studies have shown both positive and negative relationships between $\delta^{15} \mathrm{~N}$ and $\mathrm{Pb}$ in trophic networks including pinnipeds (Elorriaga-Verplancken and Aurioles-Gamboa, 2008; Sydeman and Jarman, 1998).

\section{Conclusions}

Our results show that dentin is a reliable matrix to analyze the environmental exposure to trace elements in marine mammals, particularly for $\mathrm{Cr}, \mathrm{Cu}, \mathrm{Cd}$ and $\mathrm{Pb}$, when proper tools for analysis as ICP-MS are available (Borkowska-Burnecka et al., 2010). It is an available matrix that does not require the sacrifice of organisms, sampling is possible from dead animals and from scientific collections and requires no special storage conditions.

The use of $\mathrm{Cr}$ by industries during the twentieth century was reflected in A. australis and 0 . byronia. In addition, these species have been differentially exposed to trace elements depending on their feeding areas. A pelagic diet based on squid increased the concentration of $\mathrm{Cd}$ in A. australis, whereas a nearshore or benthic diet, more common in $\mathrm{O}$. byronia, increased the concentration of $\mathrm{Cu}$ and $\mathrm{Pb}$. O. byronia has been more exposed to anthropogenic sources of $\mathrm{Pb}$ and $\mathrm{Cu}$ and as result, could have experienced synergistic effects form the exposure to multiple trace elements (Aherne et al., 1990; Whittaker et al., 2011) particularly in the case of males. Future studies could address the relationship between the concentration of trace elements in the dentin and other organs to fully understand the physiological consequences of the exposure to trace elements in pinnipeds. The combined effects of exposure to trace element along with other ecological pressures such as the interaction with fisheries and, the reduction in the size of prey consumed (De María et al., 2014a, 2014b; Drago et al., 2010; Riet Sapriza et al., 2013) could result in a higher sensitivity of 0 . byronia to anthropogenic pressures.

\section{CRediT authorship contribution statement}

Maite De María: Conceptualization, Methodology, Software, Formal analysis, Investigation, Data curation, Writing - original draft, Writing review \& editing, Visualization, Project administration, Supervision, Funding acquisition. Diana Szteren: Funding acquisition, Methodology, Investigation, Resources, Writing - review \& editing, Supervision. Javier García-Alonso: Methodology, Resources, Funding acquisition, Writing review \& editing, Supervision. Carlos E. de Rezende: Resources, Validation, Writing - review \& editing. Rodrigo Araújo Gonçalves: Validation, Data curation. José Marcus Godoy: Resources, Writing - review \& editing. Francisco R. Barboza: Methodology, Software, Formal analysis, Investigation, Data curation, Writing - review \& editing, Visualization, Supervision. 


\section{Declaration of competing interest}

The authors declare that they have no known competing financial interests or personal relationships that could have appeared to influence the work reported in this paper.

\section{Acknowledgments}

MDM acknowledges Beatriz Araujo and Camila De Maria for her laboratory support at UENF and Uruguay respectively, the financial support of the Agencia Nacional de Innovación e Innvestigación (ANII, Uruguay) throughout the MSc program 2013-2015 in Uruguay (POS NAC 2012-19147), and Comisión Sectorial de Investigación Científica (CSIC, Uruguay) for travel support to Rio de Janeiro, Brazil. MDM is very grateful with Sabrina Riverón for her assistance in the field and at the scientific collections. MDM and DS acknowledge for financial founding to Oak Foundation Mini-Grants in Marine Conservation- Duke University (grant No. 382-0296). FRB acknowledges the financial support of the German Academic Exchange Service (DAAD) - Doctoral Programmes in Germany 2015/16 (grant No.57129429). The Museo Nacional de Historia Natural (Uruguay) and the zoological collection of the Facultad de Ciencias (School of Sciences) at the Universidad de la República (University of the Republic), Uruguay, generously provided us access to their scientific collections to sample teeth. DS is very grateful to David Aurioles-Gamboa and the Pinnipeds Ecology Laboratory at CICIMAR, Instituto Politécnico Nacional, La Paz, BCS, Mexico, where teeth were cut and dentin collagen was processed for stable isotope determination (2010-2013). Additionally, DS acknowledges National Geographic Society Committee for Research and Exploration (Grant No.8978-11) which funded fieldwork and the isotopic study. We thank the two anonymous reviewers who provided helpful comments that improved the quality of the manuscripts and to Dr. Harlan Gough for his diligent proofreading of this paper.

\section{Appendix A. Supplementary data}

Supplementary data to this article can be found online at https://doi. org/10.1016/j.scitotenv.2020.141296.

\section{References}

Agusa, T., Yasugi, S., Iida, A., Ikemoto, T., Anan, Y., Kuiken, T., Osterhaus, A.D.M.E., Tanabe, S. Iwata, H., 2011. Accumulation features of trace elements in mass-stranded harbor seals (Phoca vitulina) in the North Sea coast in 2002: the body distribution and association with growth and nutrition status. Mar. Pollut. Bull. 62, 963-975. https://doi. org/10.1016/j.marpolbul.2011.02.047.

Aherne, G.W., Hardcastle, A., Nield, A.H., 1990. Cytotoxic drugs and the aquatic environment: estimation of bleomycin in river and water samples. J. Pharm. Pharmacol. 42, 741-742. https://doi.org/10.1111/j.2042-7158.1990.tb06574.x.

Al-Mahroos, F., Al-Saleh, F.S., 1997. Lead levels in deciduous teeth of children in Bahrain. Ann. Trop. Paediatr. 17 (2), 147-154.

Alomary, A., Al-Momani, I.F., Massadeh, A.M., 2006. Lead and cadmium in human teeth from Jordan by atomic absorption spectrometry: some factors influencing their concentrations. Sci. Total Environ. 369, 69-75. https://doi.org/10.1016/j. scitotenv.2006.04.023.

ANCAP, 2020. Nuestra historia [WWW Document]. URL. https://www.ancap.com.uy/ innovaportal/v/93/1/innova.front/resena-historica.html. (Accessed 24 February 2020).

Ando, N., Isono, T., Sakurai, Y., 2005. Trace elements in the teeth of Steller sea lions (Eumetopias jubatus) from the North Pacific. Ecol. Res. 20, 415-423. https://doi. org/10.1007/s11284-005-0037-X.

Arim, M., Bozinovic, F., Marquet, P.A., 2007. On the relationship between trophic position, body mass and temperature: reformulating the energy limitation hypothesis. Oikos 116, 1524-1530. https://doi.org/10.1111/j.2007.0030-1299.15768.x.

Arora, M., Bradman, A., Austin, C., Vedar, M., Holland, N., Eskenazi, B., Smith, D.R., 2012. Determining fetal manganese exposure from mantle dentine of deciduous teeth. Environ. Sci. Technol. 46, 5118-5125. https://doi.org/10.1021/es203569f.

Baranowska, I., Barchański, L., Bạk, M., Smolec, B., Mzyk, Z., 2004. X-ray fluorescence spectrometry in multielemental analysis of hair and teeth. Pol. J. Environ. Stud. 13, 639-646.

Barron, M.G., Heintz, R., Krahn, M.M., 2003. Contaminant exposure and effects in pinnipeds: implications for Steller sea lion declines in Alaska. Sci. Total Environ. 311, 111-133. https://doi.org/10.1016/S0048-9697(03)00140-2.

Barton, K., 2019. MuMIn: Multi-model Inference.
Becker, P.R., Krahn, M., 2000. Concentrations of polychlorinated biphenyls (PCB's), chlorinated pesticides, and heavy metals and other elements in tissues of belugas, Delphinapterus leucas. Mar. Fish. Rev. 62, 81-98.

Blumenthal, N., 1990. The in vitro uptake of trace elements by hydroxyapatite. In: Press, C. (Ed.), Trace Metals and Fluoride in Bones and Teeth, pp. 307-314 Boca Raton.

Boecklen, W.J., Yarnes, C.T., Cook, B.A., James, A.C., 2011. On the use of stable isotopes in trophic ecology. Annu. Rev. Ecol. Evol. Syst. 42, 411-440. https://doi.org/10.1146/ annurev-ecolsys-102209-144726.

Borkowska-Burnecka, J., Szymczycha-Madeja, A., Zyrnicki, W., 2010. Determination of toxic and other trace elements in calcium-rich materials using cloud point extraction and inductively coupled plasma emission spectrometry. J. Hazard. Mater. 182, 477-483. https://doi.org/10.1016/j.jhazmat.2010.06.057.

Bowen, W., 1997. Role of marine mammals in aquatic ecosystems. Mar. Ecol. Prog. Ser. 158, 267-274. https://doi.org/10.3354/meps158267.

Bronner, F., J., B., G., L., Martin, J., 2008. Metals in bone: aluminm, boron, cadmium, chromium, lanthanum, lead, silicon and stronium. Principles of Bone Biology. Academic Press, pp. 516-531.

Bronner, F, Stein, W.D. 1992. Modulation of bone calcium-binding sites regulates plasma calcium: an hypothesis. Calcif. Tissue Int. 50, 483-489. https://doi.org/10.1007/ BF00582159.

Burger, M., Pose Roman, D., 2010. Plomo Salud y Ambiente. Universidad de la Republica. Burone, L., Ortega, L., Franco-Fraguas, P., Mahiques, M., García-Rodríguez, F., Venturini, N., Marin, Y., Brugnoli, E., Nagai, R., Muniz, P., Bícego, M., Figueira, R., Salaroli, A., 2013. A multiproxy study between the Río de la Plata and the adjacent South-western Atlantic inner shelf to assess the sediment footprint of river vs. marineinfluence. Cont. Shelf Res. 55, 141-154. https://doi.org/10.1016/j.csr.2013.01.003.

Burton, R., Koch, P., 1999. Isotopic tracking of foraging and long-distance migration in northeastern Pacific pinnipeds. Oecologia 578-585.

Bustamante, P., Bertrand, M., 2006. Subcellular distribution of $\mathrm{Ag}, \mathrm{Cd}, \mathrm{Co}, \mathrm{Cu}, \mathrm{Fe}, \mathrm{Mn}, \mathrm{Pb}$, and $\mathrm{Zn}$ in the digestive gland of the common cuttlefish Sepia officinalis. J. Shellfish 3, 987-993.

Butler, W.T., 1995. Dentin matrix proteins and dentinogenesis. Connect. Tissue Res. 33, 59-65. https://doi.org/10.3109/03008209509016983.

Carsen, A.E., Perdomo, A., Arriola, M., 2003. Contaminación de Sedimentos del Río de la Plata y su Frente Marítimo. Doc. FREPLATA 2-4

Castiglioni, D., Rezende, C.E., Muniz, P., Muir, A.I., García-Alonso, J., 2018. Trace metals bioavailability approach in intertidal estuarine sediments and bioaccumulation in associated Nereidid Polychaetes. Bull. Environ. Contam. Toxicol. 100, 472-476. https:// doi.org/10.1007/s00128-018-2301-0.

Covington*, A.D., Lampard, G.S., Menderes, O., Chadwick, A.V., Rafeletos, G., O'Brien, P., 2001. Extended X-ray absorption fine structure studies of the role of chromium in leather tanning. Polyhedron 20,461-466. https://doi.org/10.1016/S0277-5387(00) 00611-2.

Cullen, J., Rosenthal, Y., Falkowski, P., 2001. The effect of anthropogenic CO sub (2) on the carbon isotope composition of marine phytoplankton. Limnol. Oceanogr. 50 (4).

Das, K.D., Pillet, V.S., Bouquegneau, J.M., 2003. Heavy metals in marine mammals. In: Vos, J., Bossart, G., Fournier, M., O'Shea, T. (Eds.), Toxicology of Marine Mammals. vol. 3. Taylor \& Francis, London and New York, pp. 135-167.

De María, M., Barboza, F.R., Szteren, D., 2014a. Predation of South American sea lions (Otaria flavescens) on artisanal fisheries in the Rio de la Plata estuary. Fish. Res. 149. https://doi.org/10.1016/j.fishres.2013.09.006.

De María, M., Barboza, F.R., Szteren, D., 2014b. Predation of South American sea lions (Otaria flavescens) on artisanal fisheries in the Rio de la Plata estuary. Fish. Res. 149, 69-73. https://doi.org/10.1016/j.fishres.2013.09.006.

Dehn, L.A., Follmann, E.H., Rosa, C., Duffy, L.K., Thomas, D.L., Bratton, G.R., Taylor, R.J. O'Hara, T.M., 2006. Stable isotope and trace element status of subsistence-hunted bowhead and beluga whales in Alaska and gray whales in Chukotka. Mar. Pollut. Bull. 52, 301-319. https://doi.org/10.1016/j.marpolbul.2005.09.001.

Deniro, M.J., Epstein, S., 1981. Influence of diet on the distribution of nitrogen isotopes in animals. Geochim. Cosmochim. Acta 45, 341-351. https://doi.org/10.1016/0016-7037 (81)90244-1.

Drago, M., Cardona, L., Crespo, E.A., Grandi, M.F., Aguilar, A., 2010. Reduction of skull size in South American sea lions reveals density-dependent growth during population recovery. Mar. Ecol. Prog. Ser. 420, 253-261. https://doi.org/10.3354/meps08887.

Drago, M., Franco-Trecu, V., Zenteno, L., Szteren, D., Crespo, E.A., Riet Sapriza, F.G., Machado, R., Inchausti, P., Cardona, L., 2015. Sexual foraging segregation in South American sea lions increases during the pre-breeding period in the La Plata River plume. Mar. Ecol. Prog. Ser. 1-34.

Drago, M. Cardona, L., Franco-Trecu, V., Crespo, E.A., Vales, G., Borella, F., Zenteno, L., González, E.M., Inchausti, P., 2017. Isotopic niche partitioning between two apex predators over time. J. Anim. Ecol. https://doi.org/10.1111/1365-2656.12666.

Edmonds, J.S., Shibata, Y., Prince, R.I.T., Preen, a.R., Morita, M., 1997. Elemental composition of a tusk of a dugong, Dugong dugon, from Exmouth, Western Australia. Mar. Biol. 129, 203-214. https://doi.org/10.1007/s002270050161.

Elorriaga-Verplancken, F., Aurioles-Gamboa, D., 2008. Trace metal concentrations in the hair of Zalophus californianus pups and their relation to feeding habits. Biol. Trace Elem. Res. 126, 148-164. https://doi.org/10.1007/s12011-008-8186-8.

Evans, R.D., Richner, P., Outridge, P.M., 1995. Micro-spatial variations of heavy metals in the teeth of walrus as determined by laser ablation ICP-MS: the potential for reconstructing a history of metal exposure. Arch. Environ. Contam. Toxicol. 28, 55-60.

Fair, P., Becker, P.R., 2000. Review of stress in marine mammals. J. Aquat. Ecosyst. Stress. Recover. 335-354

FAO, 2013. World Statistical Compendium for Raw Hides and Skins, Leather and Leather Footwear 1993-2012. p. 193.

Farlay, D., Boivin, G., 2012. Bone quality. In: Dionyssiotis, Y. (Ed.), Osteoporosis. InTech Europe, pp. 1-32. 
Feola, G., Mendez, H., Yafalian, M., Calero, A., Tejera, S., 2013. Informe de Efluentes de Industriales- Unidad de Efluentes industriales (Montevideo, Uruguay).

Förstner, U., Salomons, W., 1983. Trace element speciation in surface waters: interactions with particulate matter. Trace Element Speciation in Surface Waters and its Ecological Implications. Spirnger, Boston, pp. 245-273.

Fowler, S., 1990. Critical review of selected heavy metal and chlorinated hydrocarbon concentrations in the marine environment. Mar. Environ. Res. 29, 1-64.

Fowler, A.B., Alexander, J., Oskarsson, A., 2015. Toxic metals in food, in: E., M. (Ed.), handbook on the toxicology of metals. Chemosphere 123-140.

Francey, R.J., Allison, C.E., Etheridge, D.M., Trudinger, C.M., Enting, I.G., Leuenberger, M., Langenfelds, R.L., Michel, E., Steele, L.P., 2002. A 1000-year high precision record of $\delta 13 \mathrm{C}$ in atmospheric CO2. Tellus 51 (2), 170-193.

Franco-Trecu, V., Aurioles-Gamboa, D., Arim, M., Lima, M., 2012. Prepartum and postpartum trophic segregation between sympatrically breeding female Arctocephalus australis and Otaria flavescens. J. Mammal. 93, 514-521. https://doi.org/10.1644/ 11-MAMM-A-174.1.

Franco-Trecu, V., Drago, M., Riet Sapriza, F.G., Parnell, A., Frau, R., Inchausti, P., 2013. Bias in diet determination: incorporating traditional methods in Bayesian mixing models. PLoS One 8, e80019. https://doi.org/10.1371/journal.pone.0080019.

Franco-Trecu, V., Aurioles-Gamboa, D., Inchausti, P., 2014a. Individual trophic specialisation and niche segregation explain the contrasting population trends of two sympatric otariids. Mar. Biol. 161, 609-618. https://doi.org/10.1007/s00227-013-2363-9.

Franco-Trecu, V., Drago, M., Baladán, C., García-Olazábal, M.D., Crespo, E.A., Cardona, L., Inchausti, P., 2014b. Postharvesting population dynamics of the South American sea lion (Otaria byronia) in the southwestern Atlantic. Mar. Mammal Sci. https://doi. org/10.1111/mms.12197 n/a-n/a.

Fry, B., 2006. Stable Isotope Ecology, Libro. Springer https://doi.org/10.1007/0-38733745-8.

Fujise, Y., Honda, K., Tatsukawa, R., Mishima, S., 1988. Tissue distribution of heavy metals in Dall's porpoise in the northwestern Pacific. Mar. Pollut. Bull. 399-402.

García-Alonso, J., Lercari, D., Araujo, B.F., Almeida, M.G., Rezende, C.E., 2017. Total and extractable elemental composition of the intertidal estuarine biofilm of the Río de la Plata: disentangling natural and anthropogenic influences. Estuar. Coast. Shelf Sci. 187, 53-61. https://doi.org/10.1016/j.ecss.2016.12.018.

García-Alonso, J., Lercari, D., Defeo, O., 2019. Río de la plata: a neotropical estuarine system. In: Wolanski, E., Day, M., Eliott, M., Ramachandran, R. (Eds.), Coasts and Estuaries: The Future. Elsevier, Amsterdam, pp. 45-56 https://doi.org/10.1016/B978-0-12814003-1.00003-4

García-Rodríguez, F., Hutton, M., Brugnoli, E., Venturini, N., Del Puerto, L., Inda, H., Bracco, R., Burone, L., Muniz, P., 2010. Assessing the effect of natural variability and human impacts on the environmental quality of a coastal metropolitan area (Montevideo Bay, Uruguay). Panam. J. Aquat. Sci. 5, 91-100.

Georgopoulos, P.G., Roy, A., Yonone-Lioy, J., Opiekun, R., Lioy, P.J., 2001. Environmetal cooper: its dynamics and human exposure issues. J. Toxicol. Environ. Heal. Rev. 4, 341-394. https://doi.org/10.1080/15287390500196230.

Gerpe, M.S., de Moreno, J.E.a., Moreno, V.J., Patat, M.L., 2000. Cadmium, zinc and copper accumulation in the squid Illex argentinus from the Southwest Atlantic Ocean. Mar. Biol. 136 (6), 1039-1044. https://doi.org/10.1007/s002270000308. http://www. springerlink.com/openurl.asp?genre=article\&id=doi:10.1007/s002270000308.

Gil, M.N., Harvey, M. a, Esteves, J.L., 1999. Heavy metals in intertidal surface sediments from the Patagonian coast, Argentina. Bull. Environ. Contam. Toxicol. 63, 52-58.

Gotelli, N.J., Ellison, A.M., 2006. Food-web models predict species abundances in response to habitat change. PLoS Biol. 4, e324. https://doi.org/10.1371/journal.pbio.0040324.

Gray, J.S., 2002. Biomagnification in marine systems: the perspective of an ecologist. Mar. Pollut. Bull. 45, 46-52. https://doi.org/10.1016/S0025-326X(01)00323-X.

Habran, S., Pomeroy, P.P., Debier, C., Das, K., 2012. Changes in trace elements during lactation in a marine top predator, the grey seal. Aquat. Toxicol. Press 126, 455-466. https://doi.org/10.1016/j.aquatox.2012.08.011.

Halpern, B.S., Selkoe, K. a, Micheli, F., Kappel, C.V., 2007. Evaluating and ranking the vulnerability of global marine ecosystems to anthropogenic threats. Conserv. Biol. 21, 1301-1315. https://doi.org/10.1111/j.1523-1739.2007.00752.x.

Hanson, N.N., Wurster, C.M., Bird, M.I., Reid, K., Boyd, I.L., 2009. Intrinsic and extrinsic forcing in life histories: patterns of growth and stable isotopes in male Antarctic fur seal teeth. Mar. Ecol. Prog. Ser. 388, 263-272. https://doi.org/10.3354/meps08158.

Hedges, J., 1992. Global biogeochemical cycles: progress and problems. Mar. Chem. 39, 67-93.

Hedges, J.I., Keil, R., 1995. Sedimentary organic matter preservation: assessment and speculative synthesis. Mar. Chem. 49, 81-115.

Hirons, A., Schell, D., Finney, B., 2001. Temporal records of $\delta 13 C$ and $\delta 15 N$ in North Pacific pinnipeds: inferences regarding environmental change and diet. Oecologia 129, 591-601. https://doi.org/10.1007/s004420100756.

Hobson, K.A., Sease, J., 1998. Stable isotope analyses of tooth annuli reveal temporal dietary records: an example using Steller sea lions. Mar. Mammal. Sci. 14, 116-129.

Hobson, K.A., Schell, D., Renouf, D., Nosewothy, E., 1996. Stable carbon and nitrogen isotopic fractionation between diet and tissues of captive seals: implications for dietary reconstructions involving marine mammals. Can. J. Fish. Aquat. Sci. 533, 528-533.

Honda, K., Fujise, Y., Tatsukawa, R., Itano, K., Miyazaki, N., 1986. Age-related accumulation of heavy metals in bone of the striped dolphin, Stenella coeruleoalba. Mar. Environ. Res. 20, 143-160.

Instituto Cuesta Duarte, 2005. Sector Textil, Vestimenta y Cuero (Montevideo, Uruguay).

International Lead and Zinc Study Group, 2020. End used of lead [WWW document]. URL http://www.ilzsg.org/static/enduses.aspx?from $=5$.

Jakimska, A., Konieczka, P., Skóra, K., Namiesnik, J., 2011. Bioaccumulation of metals in tissues of marine animals. Part II-metal concentrations in animal tissues. Pol. J. Environ. Stud. 20,1127-1146.
Kakuschke, A.E., Valentine-Thon, S., Fonfara, S., Griesel, S., Siebert, U., Prange, A., 2006 Metal sensitivity of marine mammals: a case study of a gray seal (Halichoerus grypus). Mar. Mammal. Sci. 22, 985-996.

Karahalil, B., Aykanat, B., Ertas, N., 2007. Dental lead levels in children from two different urban and suburban areas of Turkey. Int. J. Hyg. Environ. Health 210, 107-112. https://doi.org/10.1016/j.ijheh.2006.08.009.

Kelly, J., 2000. Stable isotopes of carbon and nitrogen in the study of avian and mammalian trophic ecology. Can. J. Zool. 78, 1-27.

Kinghorn, A., Humphries, M.M., Outridge, P.M., Man, H., 2008. Teeth as biomonitors of selenium concentrations in tissues of beluga whales (Delphinapterus leucas ). Sci. Total Environ. 402, 43-50. https://doi.org/10.1016/j.scitotenv.2008.04.031.

Klevezal, G.A., 1996. Recording structures of mammals. Determination of age and reconstruction of life history. In: Balkema, R.A. (Ed.), Reconstruction of Individual Life Histories of Rodents From Their Teeth and Bone.

Kunito, T., Nakamura, S., Ikemoto, T., Anan, Y., Kubota, R., Tanabe, S., Rosas, F.C.W., Fillmann, G., Readman, J.W., 2004. Concentration and subcellular distribution of trace elements in liver of small cetaceans incidentally caught along the Brazilian coast. Mar. Pollut. Bull. 49, 574-587. https://doi.org/10.1016/j.marpolbul.2004.03.009.

Kurucz, A., Masello, A., Méndez, S., Cranston, R., Wells, P.G., 1998. Calidad ambiental del Río de la Plata. In: Wells, P.G., Daborn, G.R. (Eds.), El Río de La Plata. Una Revisón Ambiental. Dalhousie University, Halifax, Canada, pp. 71-85.

Lacerda, L., Huertas, R., Moresco, H.F., Carrasco, G., Viana, F., Lucas, R., Pessi, M., 1998. Trace metal concentration and geochemical partitioning in arroyo Carrasco wetlands, Montevideo, Uruguay. Geochim. Bras. 12, 63-74.

Lavery, T.J., Butterfield, N., Kemper, C.M., Reid, R.J., Sanderson, K., 2008. Metals and selenium in the liver and bone of three dolphin species from South Australia, 1988-2004. Sci. Total Environ. 390 (1), 77-85. https://doi.org/10.1016/j.scitotenv.2007.09.016. http:// linkinghub.elsevier.com/retrieve/pii/S0048969707009916.

Lemos, L.S., de Moura, J., Hauser-davis, R.A., Calixto de Campos, R., Siciliano, S., 2013. Ecotoxicology and Environmental Safety Small cetaceans found stranded or accidentally captured in southeastern Brazil: bioindicators of essential and non-essential trace elements in the environment. Ecotoxicol. Environ. Saf. 97, 166-175. https://doi.org/ 10.1016/j.ecoenv.2013.07.025.

Levine, M., 2011. Topics in Dental Biochemisty. Springer, New York https://doi.org/ 10.1146/annurev.bi.74.052705.100003.

Libes, S.M., 2009. Introduction to marine biogeochemistry. Mar. Chem. https://doi.org/ 10.1016/0304-4203(93)90016-H

Lotze, H.K., Lenihan, H.S., Bourque, B.J., Bradbury, R.H., Cooke, R.G., Kay, M.C., Kidwell, S.M., Kirby, M.X., Peterson, C.H., Jackson, J.B.C., Bay, M., 2006. Depletion, degradation and recovery of estuaries and coastal seas. Science (80-. ) 312, 1806-1809.

Lowry, M.S., Folk, R.L., 1990. Sex determination of the California sea lion (zalophus californianus californianus) from canine teeth. Mar. Mammal. Sci. 6, 25-31.

Marcovecchio, J.E., Ferrer, L., 2005. Distribution and geochemical partitioning of heavy metals in sediments of the Bahía Blanca Estuary, Argentina. J. Coast. Res. 214, 826-834. https://doi.org/10.2112/014-NIS.1.

Marcovecchio, J.E., Gerpe, M.S., Bastida, R.O., Rodríguez, D.H., Morón, S.G., 1994. Environmental contamination and marine mammals in coastal waters from Argentina: an overview. Sci. Total Environ. 154, 141-151.

Martin, R.B., 2006. Metal Ion Toxicity, in: Encyclopedia of Inorganic Chemistry. John Wiley \& Sons, Ltd, pp. 1-11 https://doi.org/10.1002/0470862106.ia136.

MECON, 1998. Secretaria de combustibles. disposición 285/98 [WWW document]. Combustibles. URL. http://mepriv.mecon.gov.ar/Normas/285-98.htm.

Michner, R., Kaufman, L., 2007. Stable isotope ratios as tracers in marine food webs: an update. In: Michener, R., Lajha, K. (Eds.), Stable Isotopes in Ecology and Environmental Scienes. Blackwell Publishing Ltd, pp. 238-282.

Molina-Schiller, D., Pinnedo, M.C., 2004. Using canine teeth for sex determination of the south american fur seal, Arctocephalus australis. LAJAM 3, 19-24.

Muniz, P., Danulat, E., Yannicelli, B., García-Alonso, J., Medina, G., Bícego, M.C., 2004a. Assessment of contamination by heavy metals and petroleum hydrocarbons in sediments of Montevideo Harbour (Uruguay). Environ. Int. 29, 1019-1028. https://doi org/10.1016/S0160-4120(03)00096-5.

Muniz, P., Venturini, N., Gómez-Erache, M., 2004b. Spatial distribution of chromium and lead in the benthic environment of coastal areas of the Río de la Plata estuary (Montevideo, Uruguay). Braz. J. Biol. 64, 103-116.

Naya, D.E., Arim, M., Vargas, R., 2002. Diet of South American fur seals (Arctocephalus Australis) in Isla De lobos, Uruguay. Mar. Mammal. Sci. 18, 734-745. https://doi. org/10.1111/j.1748-7692.2002.tb01070.x.

Nowak, B., Chmielnicka, J., 2000. Relationship of lead and cadmium to essential elements in hair, teeth, and nails of environmentally exposed people. Ecotoxicol. Environ. Saf. 46, 265-274. https://doi.org/10.1006/eesa.2000.1921.

Ong, C.N., Chia, S.E., Foo, S.C., Ong, H.Y., Tsakok, M., Liouw, P., 1993. Concentrations of heavy metals in maternal and umbilical cord blood. Biometals 6, 61-66. https://doi. org/10.1007/BF00154234.

Outridge, P.M., Stewart, R.E., 1999. Stock discrimination of Atlantic walrus ( Odobenus rosmarus rosmarus ) in the eastern Canadian Arctic using lead isotope and element signatures in teeth. Can. J. Fish. Aquat. Sci. 56, 105-112. https://doi.org/10.1139/ f98-155.

Outridge, P.M., Evans, R.D., Wagemannb, R., Stewartb, R.E.A., 1997. Historical trends of heavy metals and stable lead isotopes in beluga (Delphinapterus leucas) and walrus (Odobenus rosrnams rosmams) in the Canadian Arctic. Sci. Total Environ. 203, 209-219.

Páez, E., 2006. Situación de la administración del recurso lobos y leones marinos en Uruguay. In: Menafra, R., Rodriguez-Gallego, L., Scarabrino, F., Conde, D. (Eds.) Bases Para La Conservación y El Manejo de La Costa Uruguaya. Vida Silvestre Uruguay, pp. 577-583. 
Panebianco, M., Botte, S.E., Negri, M.F., Marcovecchio, J.E., Cappppozzo, H.L., 2012. Heavy metals in liver of the Franciscana dolphin, Pontoporia blainvillei, from the Southern Coast of Buenos Aires, Argentina. J. Brazilian Soc. Ecotoxicol. 7, 33-41. https://doi org/10.5132/jbse.2012.01.006.

Peña, N.I., Moreno, V.J., Marcovecchio, J.E., Perez, A., 1988. Total mercury, cadmium and lead distribution in tissues of the Southern sea lion (Otaria flavescens) in the ecosystem of Mar del Plata, Argentina. Met. Coast. Environ. Lat. Am. 1984, 140-146.

Piesco, N.P., 1994. Histology of dentin. In: Avery, J.K., Steele, P.F., Avery, N. (Eds.), Oral Development and Histology. Theime Medical Publishers, New York, pp. 213-244.

Poleto, C., Bortoluzzi, E.C., Charlesworth, S.M., Merten, G.H., 2009. Urban sediment particle size and pollutants in Southern Brazil. J. Soils Sediments 9, 317-327. https://doi.org/ 10.1007/s11368-009-0102-0.

Polizzi, P., Romero, M.B., Chiodi Boudet, L.N., Ponce de León, A., Medici, S., Costas, A., Rodríguez, D., Gerpe, M., 2017. Blood cadmium and metallothionein concentrations in females of two sympatric pinnipeds species. Mar. Pollut. Bull. 122, 446-449. https://doi.org/10.1016/j.marpolbul.2017.05.049.

Post, D., 2002. Using stable isotopes to estimate trophic position: models, methods, and assumptions. Ecology 83, 703-718.

Priest, N.D., 1993. The bioavailability and metabolism of aluminium compounds in man. Proc. Nutr. Soc. 52, 231-240. https://doi.org/10.1079/PNS19930055.

R Core Team, 2019. R: A Language and Environment for Statistical Computing. R Foundation for Statistical Computing.

Rafaelle, A., 2012. Análisis del Impacto de los Efluentes Líquidos Industriales y Domésticos en la Cuenca del Arroyo Pantanoso del Departamento de Montevideo. University of the Republic.

Reinfelder, J.R., Fisher, N.S., Luoma, S.N., Nichols, J.W., Wang, W.X., 1998. Trace element trophic transfer in aquatic organisms: a critique of the kinetic model approach. Sci. Total Environ. 219, 117-135. https://doi.org/10.1016/S0048-9697(98)00225-3.

Riet Sapriza, F.G., Costa, D.P., Franco-Trecu, V., Marín, Y., Chocca, J., González, B., Beathyate, G., Louise Chilvers, B., Hückstadt, L.a., 2013. Foraging behavior of lactating South American sea lions (Otaria flavescens) and spatial-temporal resource overlap with the Uruguayan fisheries. Deep Sea Res. Part II Top. Stud. Oceanogr. 88-89, 106-119. https://doi.org/10.1016/j.dsr2.2012.09.005.

Segura, A.M., Franco-Trecu, V., Franco-Fraguas, P., Arim, M., Tonn, W., 2015. Gape and energy limitation determine a humped relationship between trophic position and body size. Can. J. Fish. Aquat. Sci. 72, 198-205. https://doi.org/10.1139/cjfas-2014-0093.

Shafer, M.M., Siker, M., Overdier, J.T., Ramsl, P.C., Teschler-Nicola, M., Farrell, P.M., 2008 Enhanced methods for assessment of the trace element composition of Iron age bone. Sci. Total Environ. 401, 144-161. https://doi.org/10.1016/j. scitotenv.2008.02.063.

Shahidul Islam, M., Tanaka, M., 2004. Impacts of pollution on coastal and marine ecosystems including coastal and marine fisheries and approach for management: a review and synthesis. Mar. Pollut. Bull. 48, 624-649. https://doi.org/10.1016/j. marpolbul.2003.12.004.

Silvestre, F., Rocrelle, C., Rigal, L., Gaset, A., 1994. Optimum conditions for the reactivity of chromium (III) salts on collagen in the solvent tanning process. J. Chem. Technol. Biotechnol. 60, 1-6. https://doi.org/10.1002/jctb.280600102.

Sogawa, C.A., Sogawa, N., Yamamoto, T., Oda, N., Inoue, T., Onodera, K., Furuta, H., 2001 Localization of metallothionein (MT) and expression of MT isoforms induced by cadmium in rat dental pulp. Jpn. J. Pharmacol. 86, 65-72. https://doi.org/10.1254/ jjp.86.65.

Stockin, K.a., Law, R.J., Duignan, P.J., Jones, G.W., Porter, L., Mirimin, L., Meynier, L., Orams, M.B., 2007. Trace elements, PCBs and organochlorine pesticides in New Zealand common dolphins (Delphinus sp.). Sci. Total Environ. 387, 333-345. https://doi.org/ 10.1016/j.scitotenv.2007.05.016.

Sydeman, W., Jarman, W., 1998. Trace metals in seabirds, Steller sea lion, and forage fish and zooplankton from central California. Mar. Pollut. Bull. 36, 828-832.

Szefer, P., Szefer, K., Pempkowiak, J., Skwarzec, B., Bojanowski, R., Holm, E., 1994. Distribution and coassociations of selected metals in seals of the Antarctic. Environ. Pollut. 83 341-349. https://doi.org/10.1016/0269-7491(94)90156-2.

Szteren, D., 2015. Otaria flavescens and Arctocephalus australis abundance in poorly known sites: A spatial expansion of colonies? Brazilian J. Oceanogr. 63 (3), 337-346. https:// doi.org/10.1590/S1679-87592015090606303.

Szteren, D. Aurioles-Gamboa, D., 2013. Trace elements in bone of Zalophus californianus from the Gulf of California: A comparative assessment of potentially polluted areas. Ciencias Mar. 39 (3), 303-315.

Szteren, D., Naya, D.E., Arim, M., 2004. Overlap between pinniped summer diet and artisanal fishery catches in Uruguay. LAJAM 3, 119-125.

Szteren, D., Aurioles-Gamboa, D., Labrada-Martagón, V., Hernández-Camacho, C.J., De María, M., 2018. Historical age-class diet changes in south American fur seals and sea lions in Uruguay. Mar. Biol. 165. https://doi.org/10.1007/s00227-018-3315-1.

Tagliamonte, F., 2009. Detreminación de Mercurio y Cadmio en León Marino Sudamericano Otaria flavescens (Shaw, 1800) y Lobo Fino Austral Arctocephalus australis (Zimmermann, 1783) en la Costa Atlantica Uruguaya. Universidad de la República.

Téllez-Rojo, M.M., Hernández-Avila, M., González-Cossío, T., Romieu, I., Aro, A., Palazuelos, E., Schwartz, J., Hu, H., 2002. Impact of breastfeeding on the mobilization of lead from bone. Am. J. Epidemiol. 155, 420-428. https://doi.org/10.1093/aje/155.5.420.

Tjäderhane, L., Carrilho, M., Breschi, L., Tay, R.F., Pashley, D.H., 2012. Dentin basic structure and composition-an overview. Endod. Top. 20, 3-29.

Triffitt, J.T., 1985. Receptor molecules, coprecipitation and ion exchange processes in the deposition of metal ions in bone. In: Priest, N.D. (Ed.), Metals in Bone, pp. 3-20.

Turner-Walker, G., 2008. The chemical and microbial degradation of bones and teeth. Adv. Hum. Palaeopathol. 592, 3-29.

Tvinnereim, H., Eide, R., Riise, T., Fosse, G., Wesenberg, G.R., 1999. Zinc in primary teeth from children in Norway. Sci. Total Environ. 226, 201-212. https://doi.org/10.1016/ S0048-9697(98)00392-1.

Vales, D.G., Saporiti, F., Cardona, L. De Oliveira, LR., Dos Santos, R.A., Secchi, E.R., Aguilar, A., Crespo, E.A., 2013. Intensive fishing has not forced dietary change in the South American fur seal Arctophoca (=Arctocephalus) australis off Río de la Plata and adjoining areas. Aquat. Conserv. Mar. Freshwat. Ecosyst. https://doi.org/10.1002/ aqc.2397 n/a-n/a.

Van de Vijver, K.I., Hoff, P.T., Das, K., Van Dongen, W., Esmans, E.L., Jauniaux, T., Bouquegneau, J.-M., Blust, R., de Coen, W., 2003. Perfluorinated chemicals infiltrate ocean waters: link between exposure levels and stable isotope ratios in marine mammals. Environ. Sci. Technol. 37, 5545-5550.

Vander Zanden, M.., W. Fetzer, W., 2007. Global patterns of aquatic food chain length. Oikos 116, 1378-1388. doi:https://doi.org/10.1111/j.2007.0030-1299.16036.x.

Vaz-Ferreira, R., 1960. Islas de Lobos y lobos marinos en Uruguay. Boletín Informativo del Departamento Científico Técnico del SOYP (Uruguay) 1, 19-25.

Vaz-Ferreira, R., 1976. Otaria flavescens (Shaw) South American Sea Lion. Scientific Consultation on Marine Mammals, Bergen Norway.

Vaz-Ferreira, R., Ponce de León, A., 1982. Estudios sobre Arctocephalus australis (Zimmermann, 1783), lobo de dos pelos sudamericano, en el Uruguay, in: Contribuciones Del Departamento de Oceanografía. Facultad de Humanidades y Ciencias, Universidad de la República, Montevideo, Uruguay, p. 18

Viana, F., Huertas, R., Danulat, E., 2005. Heavy metal levels in fish from coastal waters of Uruguay. Arch. Environ. Contam. Toxicol. 48, 530-537. https://doi.org/10.1007/ s00244-004-0100-6.

Vincent, J.B., S.R.K., 2013. Chromium: is it essential, pharmacologically relevant, or toxic? In: Sigel, A., Sigel, H. (Eds.), Interrelations between Essential Metal Ions and Human Diseases. Life Sciences, pp. 171-198

Wakamura, M., Kandori, K., Ishikawa, T., 2000. Surface structure and composition of calcium hydroxyapatites substituted with Al (III), La (III) and Fe (III) ions. Colloids Surf. A Physicochem. Eng. Asp. 164, 297-305.

Webb, E., Amarasiriwardena, D., Tauch, S., 2005. Inductively coupled plasma-mass (ICPMS) and atomic emission spectrometry (ICP-AES): versatile analytical techniques to identify the archived elemental information in human teeth. Inf. Microchem. J. 81, 201-208. https://doi.org/10.1016/j.microc.2005.04.002.

Weise, M.J., Harvey, J.T., Costa, D.P., 2010. The role of body size in individual-based foraging strategies of a top marine predator. Ecology 91, 1004-1015.

Whittaker, M.H., Wang, G., Chen, X.Q., Lipsky, M., Smith, D., Gwiazda, R., Fowler, B.A., 2011. Exposure to $\mathrm{Pb}, \mathrm{Cd}$, and As mixtures potentiates the production of oxidative stress precursors: 30-day, 90-day, and 180-day drinking water studies in rats. Toxicol. Appl. Pharmacol. 254, 154-166. https://doi.org/10.1016/j.taap.2010.10.025.

Won, E.J., Choi, B., Hong, S., Khim, J.S., Shin, K.H., 2018. Importance of accurate trophic level determination by nitrogen isotope of amino acids for trophic magnification studies: a review. Environ. Pollut. 238, 677-690. https://doi.org/10.1016/j. envpol.2018.03.045

Worm, B., Barbier, E.B., Beaumont, N., Duffy, J.E., Folke, C., Halpern, B.S., Jackson, J.B.C. Lotze, H.K., Micheli, F., Palumbi, S.R., Sala, E., Selkoe, K.A., Stachowicz, J.J., Watson, R., 2006. Impacts of biodiversity loss on ocean ecosystem services. Science (80-. ) 314, 787-790. https://doi.org/10.1126/science.1132294.

Yamamoto, Y., Honda, K., Hidaka, H., Tatsukawa, R., 1987. Tissue distribution of heavy metals in Weddell seals (Leptonychotes weddellii). Mar. Pollut. Bull. 18, 164-169.

Zenteno, L., Crespo, E.A., Goodall, N., Aguilar, a., de Oliveira, L., Drago, M., Secchi, E.R., Garcia, N., Cardona, L., 2013. Stable isotopes of oxygen reveal dispersal patterns of the South American sea lion in the southwestern Atlantic Ocean. J. Zool. 291, 119-126. https://doi.org/10.1111/jzo.12051.

Zhou, J.L., Salvador, S.M., Liu, Y.P., Sequeira, M., 2001. Heavy metals in the tissues of common dolphins (Delphinus delphis) stranded on the Portuguese coast. Sci. Total Environ. $273,61-76$. 